\title{
Preparative-Capillary Gas Chromatographic Systems for Trace Analysis of Rum ${ }^{1}$
}

\author{
Heriberto Batiz and Elena Soltero ${ }^{2}$
}

\begin{abstract}
Three gas chromatographic systems appropriate for the reproducible rapid preparation and subsequent quantitative analysis of rum concentrates were developed and tested. The first and second systems employed preparative columns directly coupled to a capillary Golay column. Rum concentrates obtained in the preparative column were collected in a stainless steel trap of low dead space and simultaneously analyzed in the capillary system by flash heating of the trap. The third system used the same chromatographic equipment, with a $1 / 4$-in o.d. trap to transfer an amount of concentrate to a $2-\mathrm{ml}$ vial. These concentrates were subsequently analyzed with two Golay columns. In the first system, a 10-ft $20 \%$ Carbowax 20M packed preparative column coupled to a 150-ft Golay column through a 1/8-in o.d. trap gave excellent results in the analysis of the volatile fraction of rums. Ten congeners eluting before alcohol were detected in a commercial rum, six of which have not been identified. The second system, utilizing the $10-\mathrm{ft}$ Carbowax $20 \mathrm{M}$ coupled to a 7 -ft Porapak Q preparative column, was tested successfully with a $1 / 8$-in o.d. trap. About 30 congeners were detected in the same commercial Puerto Rican rum. A 7 -ft Porapak Q packed preparative column was investigated in the third system provided with a $1 / 4$-in o.d. trap. About 40 congeners were detected in two commercial Puerto Rican rums utilizing a 50-ft SE-30 Golay column in series with a 150-ft Carbowax 20M Golay column. Results demonstrate the feasibility of obtaining a rapid and complete analysis of distilled alcoholic beverages.
\end{abstract}

\section{INTRODUCTION}

The development of suitable gas chromatographic techniques for isolation, characterization, and quantitative determination of congeners present in alcoholic beverages is essential for a better evaluation of Puerto Rican rums. It is a well known fact that the vast amount of chromatographic information available in the literature about the composition of wine, beer, and distilled alcoholic beverages is still

${ }^{1}$ Manuscript submitted to Editorial Board June 21, 1974.

${ }^{2}$ Chemist and Research Assistant, respectively, Rum Pilot Plant, Agricultural Experiment Station, College of Agricultural Sciences, Mayagüez Campus, University of Puerto Rico, Río Piedras, P.R. 
insufficient to establish the influence of congeneric concentration on the quality of these products. Determination of composition of alcoholic beverages is difficult because of the small amount of congeners present and the complexity of the system.

The usual gas chromatographic methods $(14,22)$ employing analytical packed columns are seldom useful for concentrations below $10 \mathrm{p} / \mathrm{m}$. Preparation of a concentrate of the sample using selective solvent extraction $(3,5,24)$ and/or distillation $(19,21)$ prior to chromatographic analysis, either with high efficiency packed columns or capillary columns (Golay or SCOT columns), have been used; but these techniques are tedious and the final results are usually unreliable. Preparative gas chromatography followed by capillary or analytical packed-column techniques has been introduced recently for the same purpose, but again, reproducible results are very difficult to achieve.

The composition of foreign rums has been investigated extensively by Baurud and Maurice (1), Bayer (2), Bober and Haddaway (4), Fouassin (6), Kepner et al. (9), Maurel (12), Maurel and Lafarge (3), Sihto et al. (17), Suomalainen (20), Singer (18), and Stevens and Martin (19). In 1966 Maarse and ten Noever de Brau (11) identified 74 components on a heavy body Jamaica rum by means of preparative and capillary gas chromatography, mass and infrared spectroscopy. Extracts of the rum obtained in a special extractor were separated in a packed preparative column and further investigated in a liquid coated capillary column. A similar investigation by Liebich et al. (10) in 1970 showed the presence of nearly 200 compounds in a heavy body Jamaica rum. A rough estimate of the concentration of each one of these components was also given. A quantitative determination of free fatty acids in Jamaica rum was carried out by Nykanen et al. (15). Timmer et al. (23) isolated and identified a large number of nitrogen and phenolic compounds in Jamaica rum and Scotch whisky employing gas chromatography-mass spectroscopy. Nine nitrogen and seven phenolic compounds were added to the list of known components of rum and whisky. Kahn (8) summarized the literature on alcoholic beverage composition in a comprehensive report which included a tabulation of about $400 \mathrm{com}$ pounds found in whisky, wine, beer, and related alcoholic beverages produced by yeast fermentation. The concentrations of 13 components of all brands of commercial Puerto Rican rums were measured with analytical packed-column gas chromatography (7) as well as other instrumental methods $(14,16,22)$.

This study was conducted in the Rum Pilot Plant on the development of gas chromatographic systems for rapid and reproducible analysis of the congeners present in Puerto Rican rums. The present paper deals with the discussion of the development of these systems, the description 
of the equipment for carrying them out, and some of the results obtained with various commercial rums.

\section{APPARATUS, MATERIALS AND PROCEDURES}

\section{CHROMATOGRAPHIC EQUIPMENT}

Two gas chromatographic arrays, with which congeners of rum samples can be characterized and analyzed quantitatively, are described below. The first one (fig. 1) works as follows: a given volume of rum $(0.1$ to $0.5 \mathrm{ml}$ ) is separated in a preparative column placed in a gas chromatograph (B). The injection (A) is done by an automatic injector or a gas-tight syringe. The gas chromatograph (B) can be adjusted independently of the rest of the equipment to selected appropriate

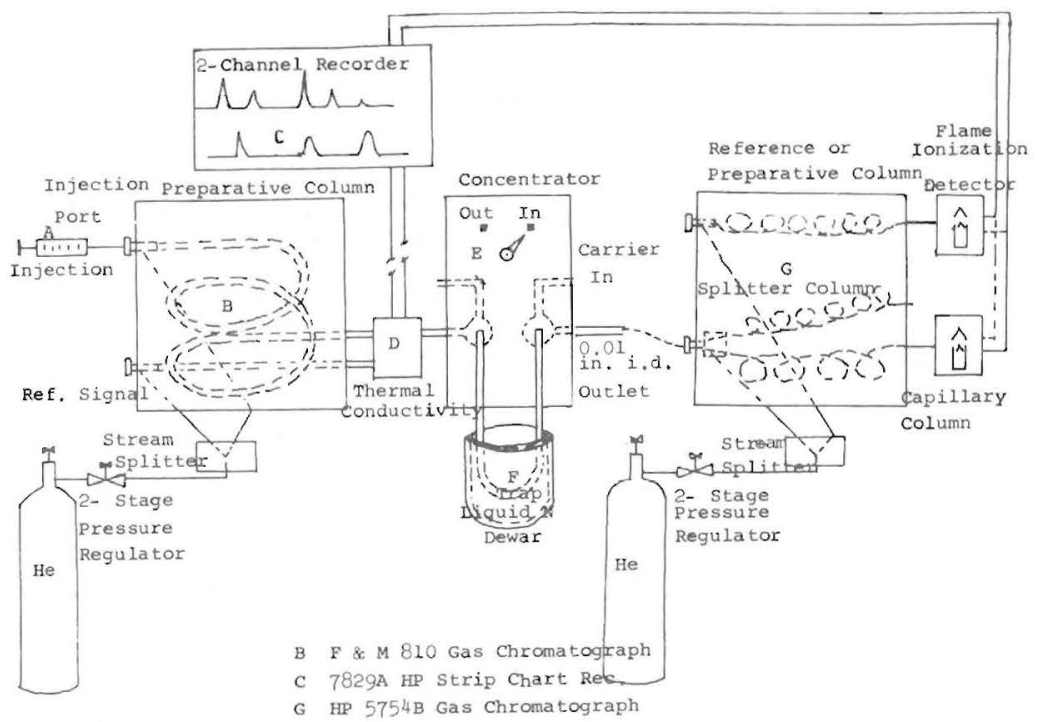

FIG. 1.-Flow diagram of chromatographic equipment and accessories required in the development of system one and two.

temperatures and carrier flows through the columns. The rum sample is fractionated according to the nature of the stationary phase of the preparative column; but in general, one of the fractions contains most of the alcohol-water mixture, while other fractions contain only either pure component or enriched mixtures of other components in alcohol or water. The desired components or mixtures which emerge from the column, as registered by recorder (C) upon entering the Thermal Conductivity Detector (D), are collected in a 1/8- or 1/16-in o.d. stainless steel trap kept in a liquid $\mathrm{N}$ bath. When the water or alcohol signal shows on the 
chromatographic chart, the carrier flow through the trap is interrupted by moving the component concentrator (E) two-way valve to the "Out" position. The sample is thus vented to outside or collected separately. The rum concentrate left in the trap is analyzed immediately by connecting the trap outlet tubing through the injector septum of a second chromatograph $(\mathrm{G})$, where the sample enters directly into a capillary Golay column. For this purpose the liquid $\mathrm{N}$ bath is removed and the auxiliary flash heater $(\mathrm{F})$ is activated for $4 \mathrm{~min}$. The temperature of the trap rises from $-195.8^{\circ} \mathrm{C}$ to $250^{\circ} \mathrm{C}$ in less than $30 \mathrm{~s}$. The chromatograph $(\mathrm{G})$ has all the necessary accessories to perform open tubular chromatography, including a heated variable sample inlet splitter and separate

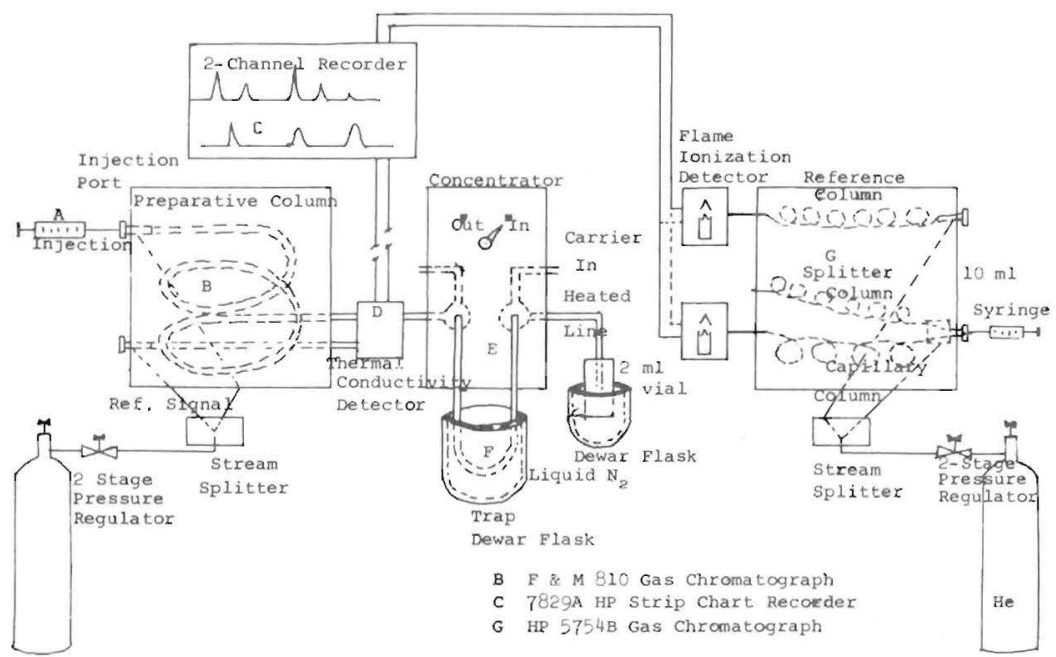

FIG. 2.-Flow diagram of chromatographic equipment and accessories required in the development of the third system.

controls for all carrier flows. The splitter column is kept open while the sample is entering the second chromatograph; then the outlet tubing is removed and the regular flow through the capillary column is restored by closing the splitter column valve.

The second array in figure 2 uses essentially the same hardware with the following changes: the gas concentrator has a higher capacity trap of stainless steel 316, 1/4-in o.d. This allows for the accumulation of concentrate from up to $5 \mathrm{~mm}$ of rum sample without flooding or any visible change in the recorder base line. The trapped sample is not analyzed automatically, but rather a second heated line is coupled to the component concentrator (E) in order to transfer the concentrate quantitatively to a small vial. The transfer is made with the vial kept in a liquid $\mathrm{N}$ bath, and it is hand-capped with a special tool as soon as the process is 
completed. The analysis of the concentrated sample which elutes from the preparative column is then accomplished by means of syringe injection.

F \& M 810 and Hewlett Packard 5754B gas chromatographs ${ }^{3}$ were used in the development of techniques for the required separations. The $\mathrm{F} \&$ M 810 gas chromatograph was fitted with a dual flame ionization detector, thermal conductivity detector, and automatic injector. The Hewlett Packard 5754B was provided with both dual flame detector and an inlet splitter for capillary Golay column work.

\section{CHROMATOGRAPHIC COLUMNS}

Three preparative columns were made and tested:

a) Stainless steel $316,10 \mathrm{ft} \times 0.5$-in o.d. packed with $20 \%$ Carbowax 20 $\mathrm{M}$ and Chromosorb $\mathrm{W}$, acid washed, 60/80 mesh.

b) Stainless steel $316,10 \mathrm{ft} \times 0.5$-in o.d. packed with Porapak Q, 50/80 mesh.

c) Stainless steel $316,7 \mathrm{ft} \times 0.5$-in o.d. packed with Porapak Q, 50/80 mesh.

Two capillary Golay columns were tested:

a) Stainless steel $316,50 \mathrm{ft} \times 0.01$-in i.d. impregnated with $\mathrm{Se} 30$ (Silicone Gum Rubber).

b) Stainless steel $316,150 \mathrm{ft} \times 0.01$-in i.d. impregnated with Carbowax 20M.

The analytical column was an $18 \mathrm{ft} \times 1 / 8$-in o.d., stainless steel 316 tube, packed with $5 \%$ Carbowax $20 \mathrm{M}$ on Chromosorb W, acid washed, $60 / 80$ mesh.

\section{DESCRIPTION OF EXPERIMENTS}

Two brands of aged light commercial Puerto Rican rums were selected for investigation, labelled R-612 and R-621, and analyzed with a regular analytical packed column and the new systems developed with the equipment shown in figures 1 and 2 .

The first system consisted of a 10-ft 20\% Carbowax 20M packed preparative column arranged with a 150-ft Carbowax 20M Golay column as in figure 1. This system was investigated at selected conditions and carrier flows. Several 1-ml preparative separations of aged commercial rum (R-612) were obtained and the corresponding concentrates collected in a 1/8-in o.d. or 0.08-in i.d. trap and further analyzed by means of the Golay column.

${ }^{3}$ Trade names are used in this publication solely for the purpose of providing information. Mention of trade names does not constitute a guarantee or warranty of the equipment by the Agricultural Experiment Station of the University of Puerto Rico or an endorsement over other equipment not mentioned. 


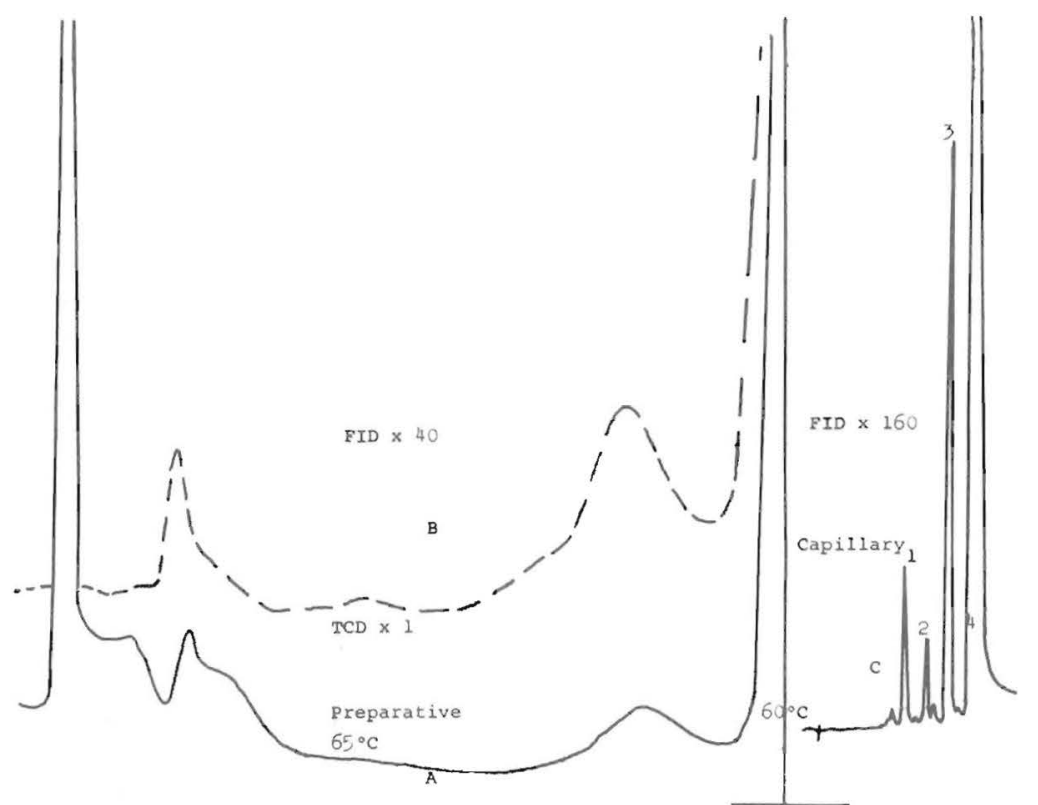

Fig. 3.-3-Preparative-capillary column chromatograms; commercial Puerto Rican rum ( $\mathrm{R}-612$ ) separated in system one. A and B: $10 \mathrm{ft} \times 0.5$-in o.d. column of $20 \%$ Carbowax $20 \mathrm{M}$ coated on Chromosorb W, A/W, 60/80 mesh; C: $150 \mathrm{ft} \times 0.01$-in i.d. Carbowax $20 \mathrm{M}$; 1 : Acetaldehyde, 2: methyl acetate, 3: ethyl acetate, 4: ethyl alcohol. Carrier flow: A and B, helium at $150 \mathrm{ml} / \mathrm{min}$ and $40 \mathrm{lb} / \mathrm{in}^{2} ; \mathrm{C}$, helium at $1 \mathrm{ml} / \mathrm{min}$ and $12 \mathrm{lb} / \mathrm{in}^{2}$. Sample collected from 0 to 1 position.
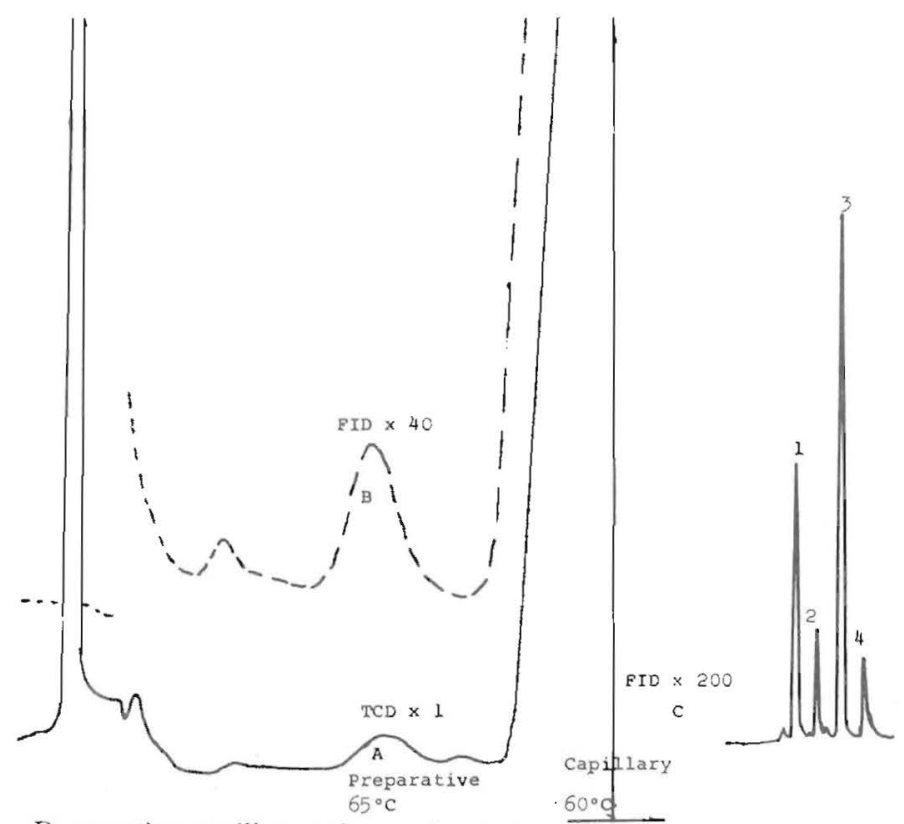

Fig. 4.-Preparative-capillary column chromatograms; commercial Puerto Rican rum (R-612) separated in system one. A and B: $10 \mathrm{ft} \times 0.5$-in o.d. column of $20 \%$ Carbowax $20 \mathrm{M}$ coated on Chromosorb W, A/W, 60/80 mesh; C: $150 \mathrm{ft} \times 0.01$-in i.d. Carbowax 20M; 1 : Acetaldehyde, 2: methyl acetate, 3: ethyl acetate, 4: ethyl alcohol. Carrier flow: A and B, helium at $100 \mathrm{ml} / \mathrm{min}$ and $40 \mathrm{lb} / \mathrm{in}^{2}$; C, helium at $1 \mathrm{ml} / \mathrm{min}$ and $12 \mathrm{lb} / \mathrm{in}^{2}$. Sample collected from 0 to 1 position. 
Two representative preparative-capillary column chromatograms are shown in figures 3 and 4 . The conditions for these separations are given in table 1 . The two chromatograms in figure 3 were registered at carrier flows of $150 \mathrm{ml} / \mathrm{min}$ and $40 \mathrm{lb} / \mathrm{in}^{2}$ for the preparative run for $\mathrm{A}$ and $\mathrm{B}$ signals and at $1 \mathrm{ml} / \mathrm{min}$ and $12 \mathrm{lb} / \mathrm{in}^{2}$ for the capillary run for $\mathrm{C}$ signal. The chromatograms of figure 4 were registered at $100 \mathrm{ml} / \mathrm{min}$ and 40 $\mathrm{lb} / \mathrm{in}^{2}$ for $\mathrm{A}$ and $\mathrm{B}$ signals and at $1 \mathrm{ml} / \mathrm{min}$ and $12 \mathrm{lb} / \mathrm{in}^{2}$ for $\mathrm{C}$ signal. For comparison with existing techniques the work represented by the chromatograms (Fig. 5, 6, 7, 8) was also accomplished at conditions given in tables 1 and 2. Figure 5 is a $1-\mathrm{ml}$ preparative chromatogram of standard solution (P-26) described below, in which congeneric concentration is similar to that of an average rum, carried out at carrier flow of $100 \mathrm{ml} / \mathrm{min}$

TABLE 1.-Gas chromatographic conditions for figures 3,4 , and 6

\begin{tabular}{|c|c|c|}
\hline & $\begin{array}{l}\text { Preparative run } \\
\text { (F \& M 810) } \\
\text { (fig. } 3 \text { and } 4 \text { ) }\end{array}$ & $\begin{array}{c}\text { Capillary run } \\
\text { (HP 5754B) } \\
\text { (fig. } 3,4 \text { and } 6 \text { ) }\end{array}$ \\
\hline Sample volume & $1 \mathrm{ml}$ & $\begin{array}{l}\text { Concentrate } \\
\text { (fig. 1) }\end{array}$ \\
\hline Injection technique & Automatic & $\begin{array}{l}\text { Concentrator } \\
\text { (1/8-in o.d.) }\end{array}$ \\
\hline Injection splitter ratio & - & $1: 31$ \\
\hline Detector splitter ratio & $1: 44$ & - \\
\hline Carrier & Helium & Helium \\
\hline Carrier flow & $\begin{array}{l}150,100 \mathrm{ml} / \mathrm{min} \\
\left(40 \mathrm{lb} / \mathrm{in}^{2}\right)\end{array}$ & $1 \mathrm{ml} / \mathrm{min}\left(12 \mathrm{lb} / \mathrm{in}^{2}\right)$ \\
\hline Oven temperature & $65^{\circ} \mathrm{C}$ & $60^{\circ} \mathrm{C}$ \\
\hline Oven temperature program & - & $\begin{array}{l}30^{\circ} \mathrm{C} / \mathrm{min} \\
\quad\left(60^{\circ} \text { to } 130^{\circ} \mathrm{C}\right)\end{array}$ \\
\hline Injection port temperature & $240^{\circ} \mathrm{C}$ & $240^{\circ} \mathrm{C}$ \\
\hline Injection splitter temperature & 一 & $140^{\circ} \mathrm{C}$ \\
\hline \multicolumn{3}{|l|}{ Detector temperature: } \\
\hline FID temperature & $240^{\circ} \mathrm{C}$ & $240^{\circ} \mathrm{C}$ \\
\hline TCD temperature & $285^{\circ} \mathrm{C}$ at $150 \mathrm{~V}$ & \\
\hline \multicolumn{3}{|l|}{ FID: } \\
\hline Hydrogen & $\begin{array}{l}35 \mathrm{ml} / \mathrm{min} \\
\quad\left(12 \mathrm{lb} / \mathrm{in}^{2}\right)\end{array}$ & $\begin{array}{l}35 \mathrm{ml} / \mathrm{min} \\
\left(12 \mathrm{lb} / \mathrm{in}^{2}\right)\end{array}$ \\
\hline Air & $\begin{array}{r}450 \mathrm{ml} / \mathrm{min} \\
\left(33 \mathrm{lb} / \mathrm{in}^{2}\right)\end{array}$ & $\begin{array}{l}450 \mathrm{ml} / \mathrm{min} \\
\left(33 \mathrm{lb} / \mathrm{in}^{2}\right)\end{array}$ \\
\hline \multicolumn{3}{|l|}{ Column material: } \\
\hline Support & $\begin{array}{l}60 / 80 \mathrm{a} / \mathrm{w}, \text { Chro- } \\
\text { mosorb W }\end{array}$ & None \\
\hline Liquid phase & $20 \%$ Carbowax 20M & $\begin{array}{l}\text { Carbowax 20M } \\
\text { (Golay) }\end{array}$ \\
\hline Tubing & $\begin{array}{l}\text { Stainless steel } \\
316 \\
(10 \mathrm{ft} \times 0.5 \text {-in } \\
\text { o.d.) }\end{array}$ & $\begin{array}{l}\text { Stainless steel } \\
\quad 316 \\
(150 \mathrm{ft} \times 0.01 \text {-in } \\
\text { i.d. })\end{array}$ \\
\hline
\end{tabular}




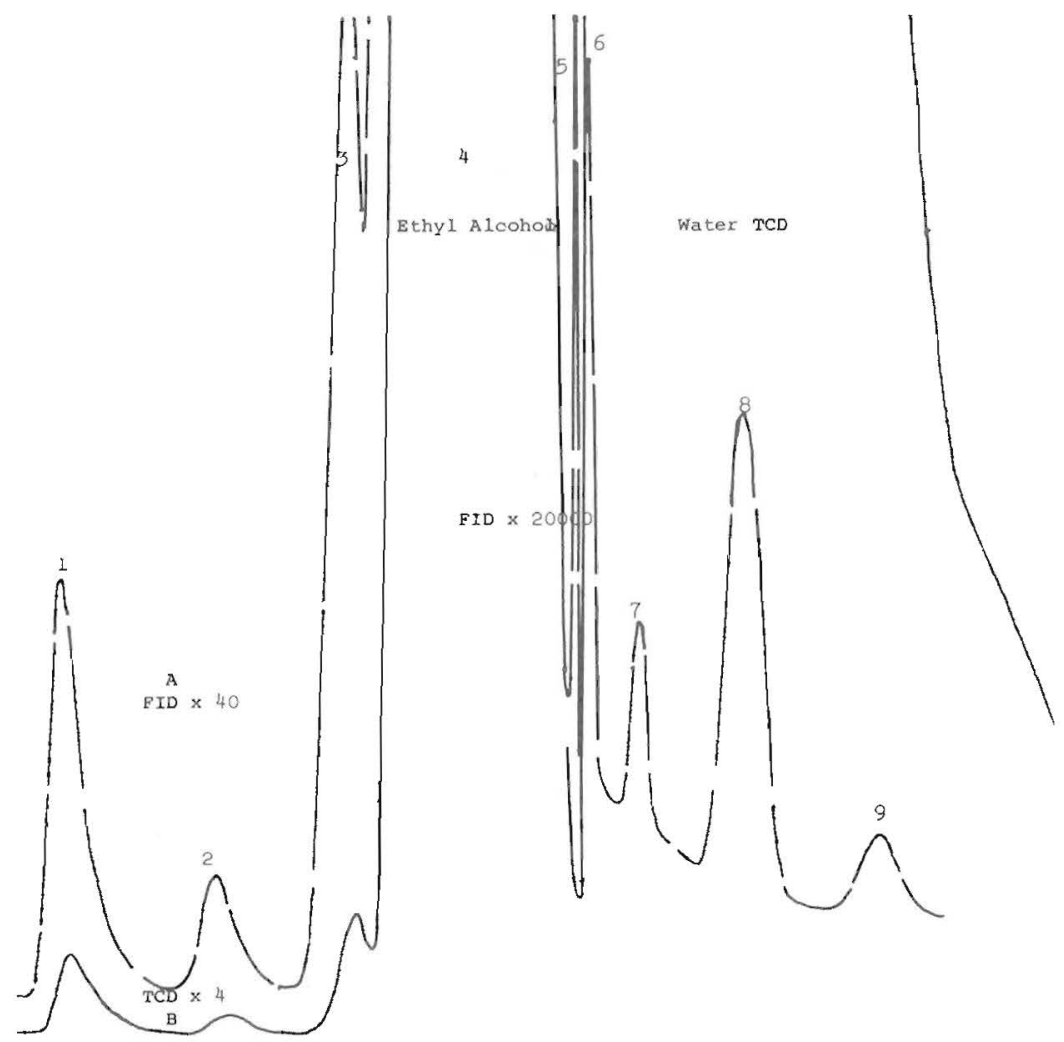

Fig. 5.-Preparative column chromatograms; standard sample (P-26) on $10 \mathrm{ft} \times 0.5$-in o.d. column of $20 \%$ Carbowax 20M coated on Chromosorb W, A/W, $60 / 80$ mesh; 1 : Acetaldehyde, 2: methyl acetate, 3: ethyl acetate, 4: ethyl alcohol, 5: water effect in the flame ionization detector, 6: propyl alcohol, 7: isobutyl alcohol, 8: isoamyl alcohol-butyl alcohol-isoamyl acetate, 9: amyl alcohol. Carrier flow: helium at $150 \mathrm{ml} / \mathrm{min}$ and $40 \mathrm{lb} / \mathrm{in}^{2}$.

and $40 \mathrm{lb} / \mathrm{in}^{2}$. Figure 6 is a $1-\mu \mathrm{l}$ capillary separation with the Carbowax $20 \mathrm{M}$ Golay column of solution prepared with equal volumes of acetaldehyde, ethyl alcohol, methyl, ethyl, and isoamyl esters, and propyl, butyl, isobutyl, isoamyl, and amyl alcohols. This chromatogram was taken at a carrier flow of $1 \mathrm{ml} / \mathrm{min}$ and $12 \mathrm{lb} / \mathrm{in}^{2}$. Figures 7 and 8 are chromatographic separations of $3 \mu \mathrm{l}$ of $\mathrm{R}-612$ and R-621, respectively, utilizing the 18 -ft analytical packed column of $5 \%$ Carbowax $20 \mathrm{M}$, set at carrier flow of $12 \mathrm{ml} / \mathrm{min}$ and $40 \mathrm{lb} / \mathrm{in}^{2}$.

The composition of standard solution (P-26) is given below:

Component

Acetaldehyde

Methyl acetate
Concentration $\left(\mathrm{mg} / 100 \mathrm{ml}\right.$ at $\left.80^{\circ} \mathrm{P}\right)$ 


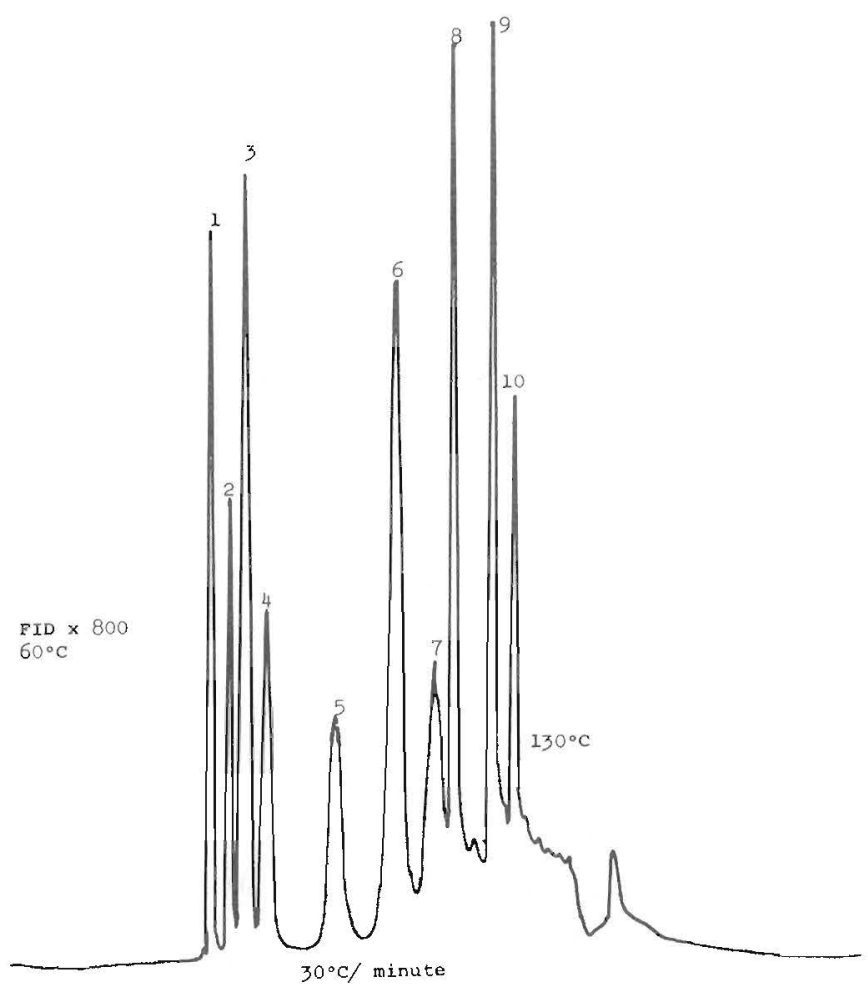

Fig. 6.-Capillary column chromatogram; standard sample (P-26) on $150 \mathrm{ft} \times 0.01$-in i.d. Carbowax 20M column. 1: Acetaldehyde, 2: methyl acetate, 3: ethyl acetate, 4 : thyl alcohol. 5: propyl alcohol, 6: Lisobutyl alcohol, 7: isoamyl acetate, 8: butyl alcohol, 9: isoamyl alcohol and 10 amyl alcohol. Carrier flow: helium at $1 \mathrm{ml} / \mathrm{min}$ and $12 \mathrm{lb} / \mathrm{in}^{2}$.

$\begin{array}{lr}\text { Ethyl acetate } & 9.0 \\ \text { Acetal } & 7.6 \\ \text { Propyl alcohol } & 14.5 \\ \text { Isobutyl alcohol } & 6.4 \\ \text { Isoamyl acetate } & 3.4 \\ \text { Butyl alcohol } & 3.2 \\ \text { Isoamyl alcohol } & 19.5 \\ \text { Amyl alcohol } & 4.9\end{array}$

A single 10-ft Porapak Q preparative column was investigated with 1 $\mathrm{ml}$ of standard sample P-26 in an arrangement similar to figure 1 . The preparative chromatogram is shown in figure 9 , and conditions are shown in table 3. A similar 7-ft Porapak Q preparative column was also tested. This shorter Porapak Q column was more suitable although it had a poorer resolution (fig. 10). Porapak Q phase removes water first, followed 

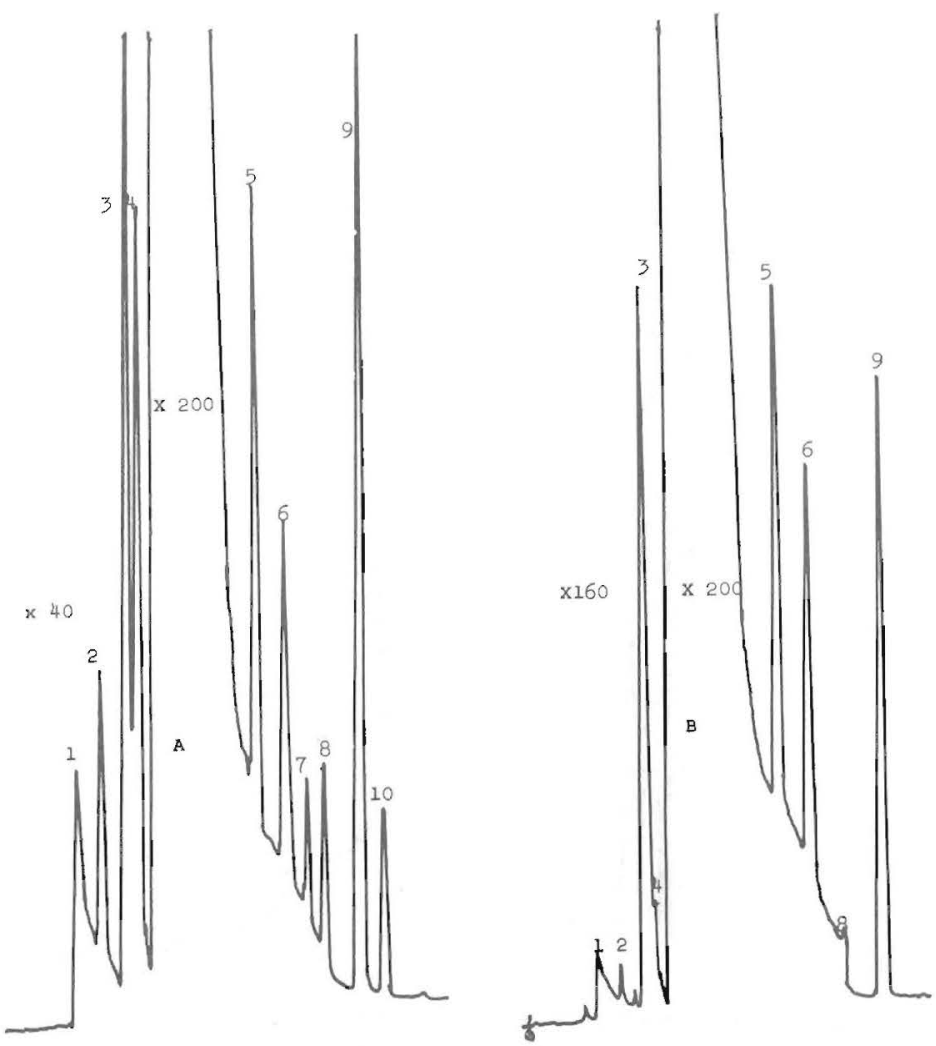

Fig. 7.-High efficiency analytical packed column chromatograms; $18 \mathrm{ft} \times 1 / 8$-in o.d. column of $5 \%$ Carbowax 20M on Chromosorb W, A/W, 60/80 mesh. A: Standard solution (P-26). B: commercial Puerto Rican rum (R-612), 1: Acetaldehyde, 2: methyl acetate, 3: ethyl acetate, 4: acetal, 5: propyl alcohol, 6: isobutyl alcohol, 7: isoamyl acetate, 8: butyl alcohol, 9: isoamyl alcohol, 10: amyl alcohol. Carrier flow: helium at $12 \mathrm{ml} / \mathrm{min}$ and 40 $\mathrm{lb} / \mathrm{in}^{2}$.

by acetaldehyde, ethyl alcohol, and other congeners of alcoholic beverages. The purpose of these tests was to determine the amount of concentrate that could be collected with a single preparative run for direct injection into capillary Golay columns. Tests were conducted with 0.1- to $0.4-\mathrm{ml}$ rum samples, and a 1/8-in o.d. trap. Separation of samples larger than a $4 \mathrm{ml}$ overflowed the $1 / 8$-in o.d. trap, and it was necessary to stop the carrier flow. Chromatograms of the rum concentrates, using direct injection through the concentrator, were somewhat useful but lack of resolution for the heavy fraction was observed.

A second system which consisted of 7 -ft Porapak Q packed preparative column followed by a 10 -ft $20 \%$ Carbowax $20 \mathrm{M}$ packed preparative 
column coupled to the 150-ft Carbowax 20M Golay column through component concentrator as in figure 1 was also developed and investigated extensively. The Porapak Q preparative column was placed in the F \& M 810 Gas Chromatograph (B) and the 20\% Carbowax 20M preparative column in the Hewlett Packard 5754B Gas Chromatograph $(\mathrm{G})$ in parallel with the Carbowax $20 \mathrm{M}$ Golay column. The carrier flow

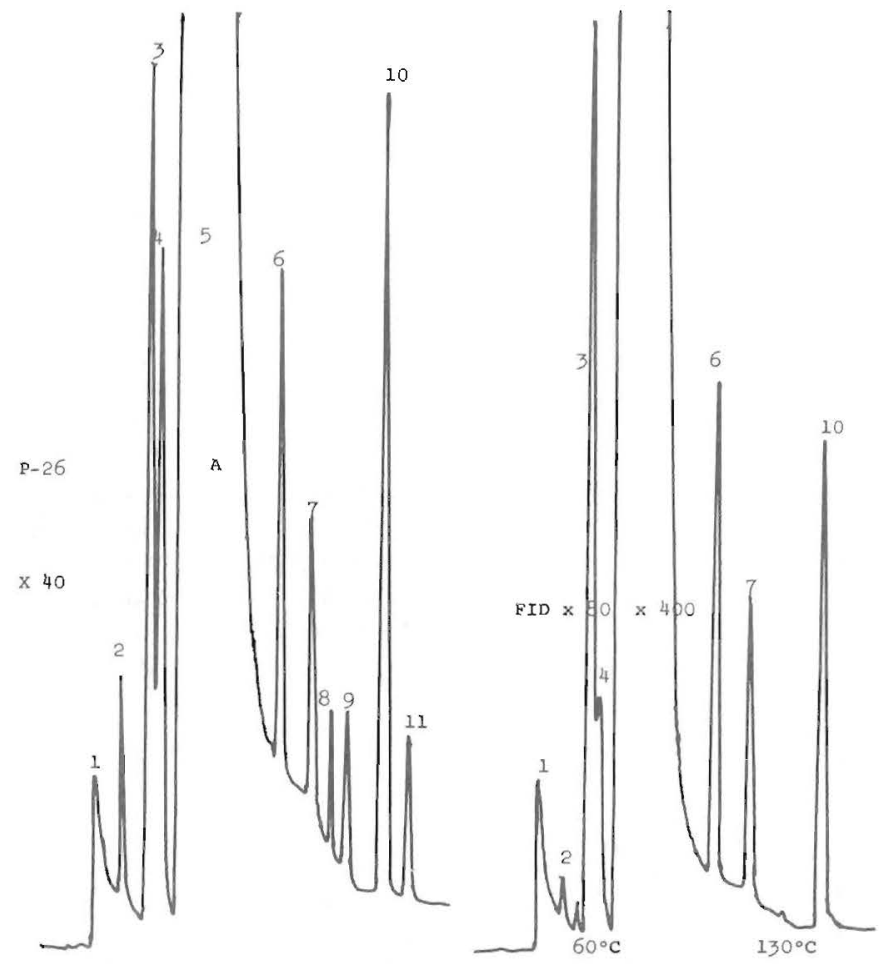

Fig. 8. - High efficiency analytical packed column chromatograms; $18 \mathrm{ft} \times 1 / 8$-in o.d. column of $5 \%$ Carbowax 20M coated on Chromosorb W, A/W, 60/80 mesh. A: Standard solution (P-26), B: commercial Puerto Rican rum (R-621); 1: Acetaldehyde, 2: methyl acetate, 3: ethyl acetate, 4: acetal, 5: ethyl alcohol, 6: propyl alcohol, 7: isobutyl alcohol, 8: isoamyl acetate, 9: butyl alcohol, 10: isoamyl alcohol, 11: amyl alcohol. Carrier flow: helium at $12 \mathrm{ml} / \mathrm{min}$ and $40 \mathrm{lb} / \mathrm{in}^{2}$.

was directed from the Porapak $\mathrm{Q}$ to the Carbowax 20M preparative column. More than 20 preparative chromatograms were taken with this arrangement at different conditions and sample volumes. Chromatograms of 0.1 to $1 \mathrm{ml}$ of $\mathrm{R}-612$ were carried out by direct injection of the rum concentrate with component concentrator provided with a $1 / 16$-in o.d. trap for the $0.1-\mathrm{ml}$ sample and a 1/8-in o.d. trap for the other. The capillary separation corresponding to the 1 - $\mathrm{ml}$ preparative chromatogram. 


\begin{tabular}{|c|c|c|}
\hline & $\begin{array}{l}\text { Preparative run } \\
\text { (F \& M 810) } \\
\text { (fig. 5) }\end{array}$ & $\begin{array}{l}\text { Analytical run } \\
\text { (HP 5750B) } \\
\text { (fig. } 7 \text { and 8) }\end{array}$ \\
\hline Sample volume & $1 \mathrm{ml}$ & $3 \mu \mathrm{l}$ \\
\hline Injection technique & Automatic & Syringe \\
\hline Detector splitter ratio & $1: 44$ & - \\
\hline Carrier & Helium & Helium \\
\hline Carrier flow & $\begin{array}{c}150 \mu \mathrm{l} / \mathrm{min} \text { at } \\
\left(40 \mathrm{lb} / \mathrm{in}^{2}\right)\end{array}$ & $\begin{array}{c}12 \mu \mathrm{l} / \mathrm{min}(40 \\
\left.\mathrm{lb} / \mathrm{in}^{2}\right)\end{array}$ \\
\hline Oven temperature & $65^{\circ} \mathrm{C}$ & $60^{\circ} \mathrm{C}$ \\
\hline Oven temperature program & $\begin{array}{c}20^{\circ} \mathrm{C} / \mathrm{min}\left(65^{\circ}\right. \\
\left.\text { to } 150^{\circ} \mathrm{C}\right)\end{array}$ & $\begin{array}{l}20^{\circ} \mathrm{C} / \mathrm{min}\left(50^{\circ}\right. \\
\left.\text { to } 150^{\circ} \mathrm{C}\right)\end{array}$ \\
\hline Injection port temperature & $240^{\circ} \mathrm{C}$ & $240^{\circ} \mathrm{C}$ \\
\hline \multicolumn{3}{|l|}{ Detector temperature: } \\
\hline FID temperature & $240^{\circ} \mathrm{C}$ & $240^{\circ} \mathrm{C}$ \\
\hline TCD temperature & $285^{\circ} \mathrm{C}$ at $150 \mathrm{~V}$ & - \\
\hline \multicolumn{3}{|l|}{ FID: } \\
\hline Hydrogen & $\begin{array}{c}35 \mathrm{ml} / \mathrm{min}(12 \\
\left.\mathrm{lb} / \mathrm{in}^{2}\right)\end{array}$ & $\begin{array}{c}35 \mathrm{ml} / \mathrm{min}(12 \\
\left.\mathrm{lb} / \mathrm{in}^{2}\right)\end{array}$ \\
\hline Air & $\begin{array}{l}450 \mathrm{ml} / \mathrm{min}(33 \\
\left.\mathrm{lb} / \mathrm{in}^{2}\right)\end{array}$ & $\begin{array}{l}450 \mathrm{ml} / \mathrm{min}(33 \\
\left.\mathrm{lb} / \mathrm{in}^{2}\right)\end{array}$ \\
\hline \multicolumn{3}{|l|}{ Column materiat: } \\
\hline Surport & $\begin{array}{l}\text { 60/80 a/w, Chro- } \\
\text { inosorb WW }\end{array}$ & $\begin{array}{l}60 / 80 \text { a/w, Chro- } \\
\text { mosorb W }\end{array}$ \\
\hline Liquid phase & $20 \%$ Carbowax $20 \mathrm{M}$ & $5 \%$ Carbowax $20 \mathrm{M}$ \\
\hline Tubing & $\begin{array}{l}\text { Stainless steel } \\
316(10 \mathrm{ft} \times 0.5 \text {-in } \\
\text { o.d.) }\end{array}$ & $\begin{array}{l}\text { Stainless steel } \\
316(18 \mathrm{ft} \times 1 / 8 \text {-in } \\
\text { o.d. })\end{array}$ \\
\hline
\end{tabular}

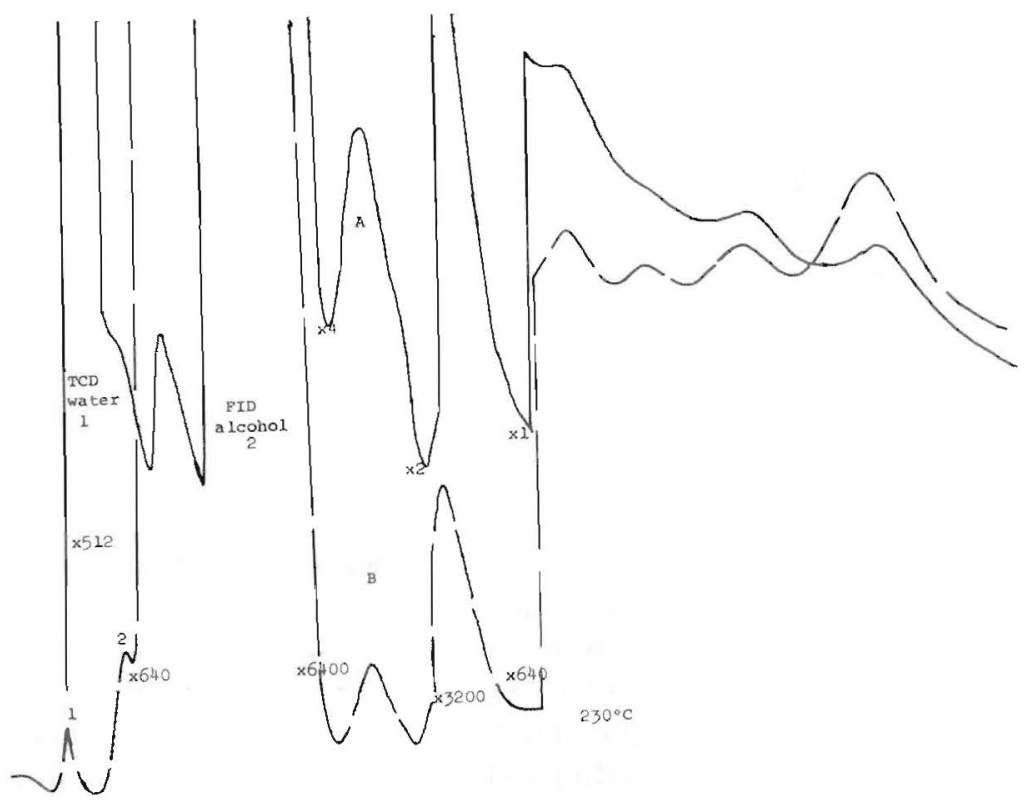

Fig. 9.-Preparative column chromatogram; $1 \mathrm{ml}$ commercial rum (R-612) taken by syringe injection. Preparative column: Porapak Q, 50/80 mesh, $10 \mathrm{ft} \times 0.05$-in o.d. Carrier flow: helium at $102 \mathrm{ml} / \mathrm{min}$ and $60 \mathrm{lb} / \mathrm{in}^{2}$. 
TABLE 3.-Gas chromatographic conditions for figures 11,12 , and 13

\begin{tabular}{|c|c|c|}
\hline & $\begin{array}{c}\text { Preparative run } \\
\text { (F \& M 810, HP 5754B) } \\
\text { (fig. } 11 \text { and 12) }\end{array}$ & $\begin{array}{l}\text { Capillary run } \\
\text { (HP 5754B) } \\
\text { (fig. } 11 \text { and 13) }\end{array}$ \\
\hline Sample volume & $1,0.4 \mathrm{ml}$ & $\begin{array}{l}\text { Concentrate } \\
\text { (fig. 1) }\end{array}$ \\
\hline Injection technique & Automatic & $\begin{array}{l}\text { Concentrator } \\
\text { ( } 1 / 8 \text {-in o.d.) }\end{array}$ \\
\hline Injection splitter ratio & - & $1: 31$ \\
\hline Detector splitter ratio & $1: 44$ & - \\
\hline Carrier & Helium & Helium \\
\hline Carrier flow & $\begin{array}{l}150 \mathrm{ml} / \mathrm{min} \text { at }(40 \\
\left.\mathrm{lb} / \mathrm{in}^{2}\right)\end{array}$ & $\underset{\left.\mathrm{lb} / \mathrm{in}^{2}\right)}{1 \mathrm{ml} / \mathrm{min}}(12$ \\
\hline Oven temperature & $\begin{array}{l}65^{\circ} \text { to } 150^{\circ} \mathrm{C}(\mathrm{HP} \\
5754 \mathrm{~B}) \\
105^{\circ} \text { to } 220^{\circ} \mathrm{C}(\mathrm{F} \& \mathrm{M} \\
810)\end{array}$ & $60^{\circ} \mathrm{C}$ \\
\hline Oven temperature program & $60^{\circ} \mathrm{C} / \mathrm{min}$ & $\begin{array}{l}30^{\circ} \mathrm{C} / \mathrm{min}\left(60^{\circ}\right. \\
\left.130^{\circ} \mathrm{C}\right)\end{array}$ \\
\hline Injection port temperature & $240^{\circ} \mathrm{C}$ & $240^{\circ} \mathrm{C}$ \\
\hline Injection splitter temperature & - & $140^{\circ} \mathrm{C}$ \\
\hline \multicolumn{3}{|l|}{ Detector temperature: } \\
\hline FID temperature & $240^{\circ} \mathrm{C}$ & $240^{\circ} \mathrm{C}$ \\
\hline TCD temperature & $285^{\circ} \mathrm{C}$ at $150 \mathrm{~V}$ & - \\
\hline \multicolumn{3}{|l|}{ FID: } \\
\hline Hydrogen & $\begin{array}{c}35 \mathrm{ml} / \mathrm{min}(12 \\
\left.\mathrm{lb} / \mathrm{in}^{2}\right)\end{array}$ & $\begin{array}{l}35 \mathrm{ml} / \mathrm{min}(12 \\
\left.\mathrm{lb} / \mathrm{in}^{2}\right)\end{array}$ \\
\hline Air & $\begin{array}{l}450 \mathrm{ml} / \mathrm{min}(33 \\
\left.\mathrm{lb} / \mathrm{in}^{2}\right)\end{array}$ & $\begin{array}{l}450 \mathrm{ml} / \mathrm{min}(33 \\
\left.\mathrm{lb} / \mathrm{in}^{2}\right)\end{array}$ \\
\hline \multicolumn{3}{|l|}{ Column material: } \\
\hline Support & $\begin{array}{l}60 / 80, a / w, \text { Chro- } \\
\text { mosorb W }\end{array}$ & None \\
\hline Liquid phase & $20 \%$ Carbowax $20 \mathrm{M}$ & $\begin{array}{l}\text { Carbowax 20M } \\
\text { (Golay) }\end{array}$ \\
\hline Tubing & $\begin{array}{l}(10 \mathrm{ft} \times 0.5-\mathrm{in} \\
\quad 0 . \mathrm{d} .)\end{array}$ & $\begin{array}{l}\text { Stainless steel } \\
316(150 \mathrm{ft} \times 0.01 \text {-in } \\
\text { i.d. })\end{array}$ \\
\hline Support & None & \\
\hline Liquid phase & Porapak Q, 50/80 & \\
\hline Tubing & $\begin{array}{l}\text { Stainless steel } \\
316(7 \mathrm{ft} \times 0.5 \text {-in } \\
\text { o.d. })\end{array}$ & \\
\hline
\end{tabular}

of figure $11 \mathrm{~A}$ is shown in figure $11 \mathrm{~B}$. For the $0.4-\mathrm{ml}$ separation, the preparative chromatogram is in figure 12 and the capillary chromatogram in figure 13. For the 0.1-ml separation the preparative chromatogram is in figure 14 and the capillary chromatogram in figure 15 . Conditions for figures 11 to 15 are given in tables 4 and 5 .

The third system consisted of a 7-ft Porapak Q packed preparative 

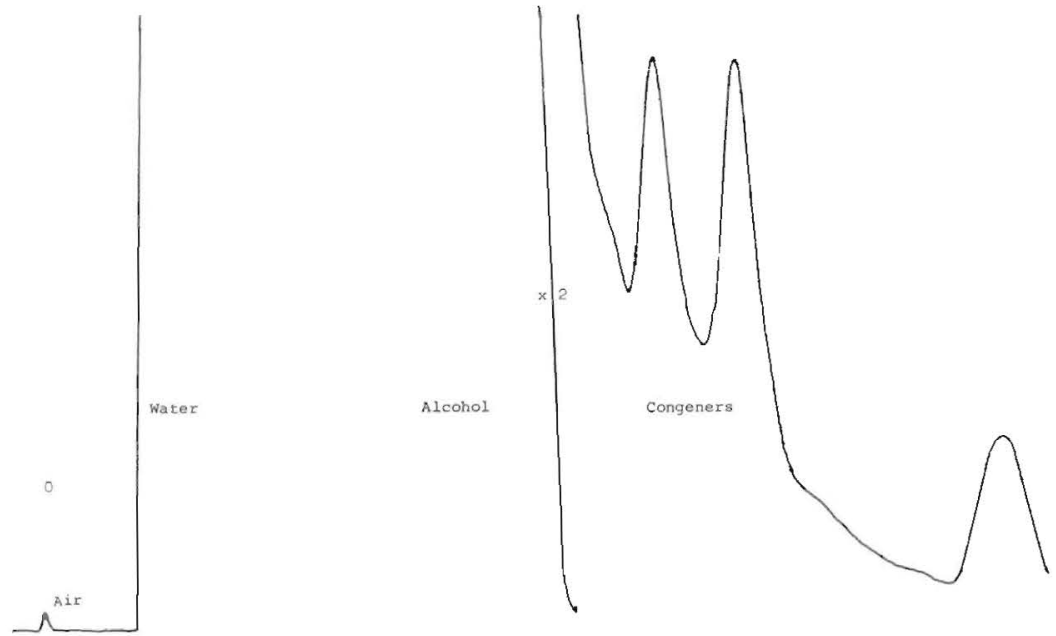

Fig. 10.-Preparative column chromatogram; $5 \mathrm{ml}$ commercial rum (R-612) taken by syringe injection. Preparative column: Porapak Q, 50/80 mesh, 0.5-in o.d. Carrier flow: helium at $100 \mathrm{ml} / \mathrm{min}$ and $40 \mathrm{Ib} / \mathrm{in}^{2}$.

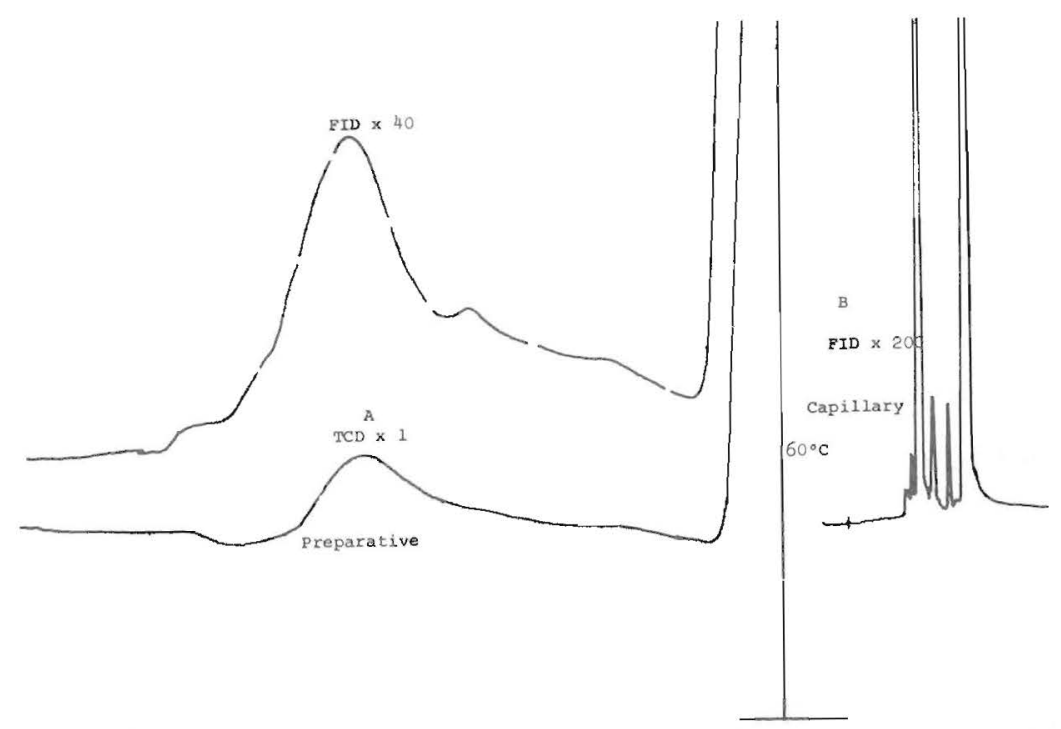

Fig. 11.-Preparative-capillary column chromatograms; $1 \mu \mathrm{l}$ commercial rum (R-612) taken in system two. A: Preparative columns: Porapak Q, $7 \mathrm{ft} \times 0.5$-in o.d. followed by $20 \%$ Carbowax 20M coated on Chromosorb W, A/W, $60 / 80$ mesh, $10 \mathrm{ft} \times 0.5$-in o.d. B: capillary column: Carbowax 20M, $150 \mathrm{ft} \times 0.01$-in i.d. Carrier flow: preparative columns, helium at $150 \mathrm{ml} / \mathrm{min}$ and $40 \mathrm{lb} / \mathrm{in}^{2}$; capillary column, helium at $1 \mathrm{ml} / \mathrm{min}$ and $12 \mathrm{lb} / \mathrm{in}^{2}$. Sample collected from 0 to 1 positions. 

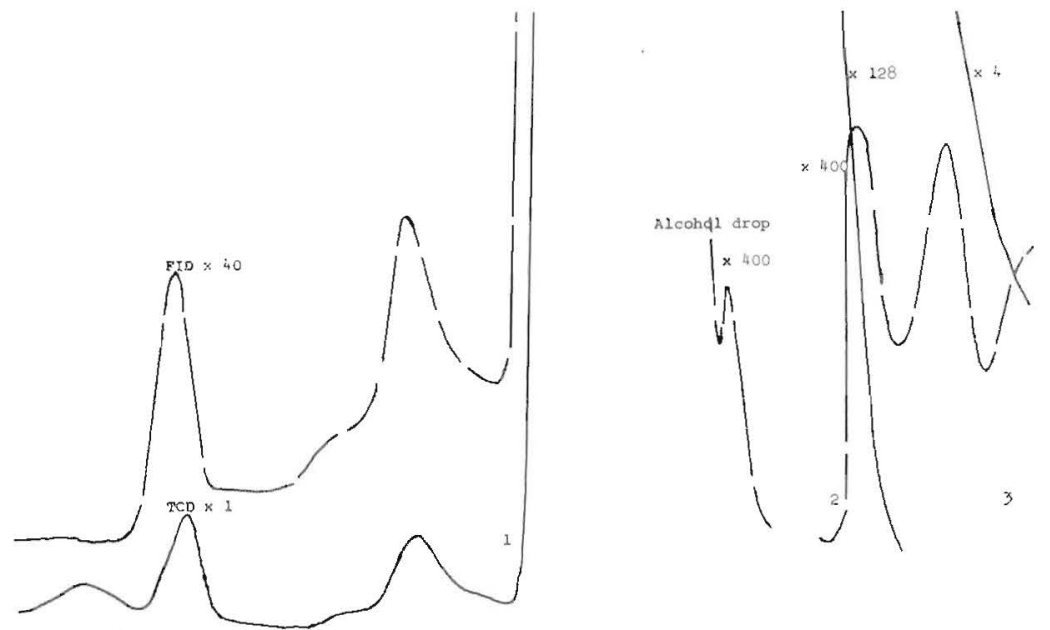

FIG. 12.-Preparative column chromatogram; $0.4 \mathrm{ml}$ commercial rum (R-612) taken in system two. Preparative columns: Porapak Q, $50 / 80$ mesh, $7 \mathrm{ft} \times 0.5$-in o.d. followed by $20 \%$ Carbowax 20M coated on Chromosorb W, A/W, 60/80 mesh, $10 \mathrm{ft} \times 0.5$-in o.d. Carrier flow: helium at $150 \mathrm{ml} / \mathrm{min}$ and $40 \mathrm{lb} / \mathrm{in}^{2}$. Sample collected from positions 0 to 1 and 2 and 3; from 1 to 2 the sample was discarded.

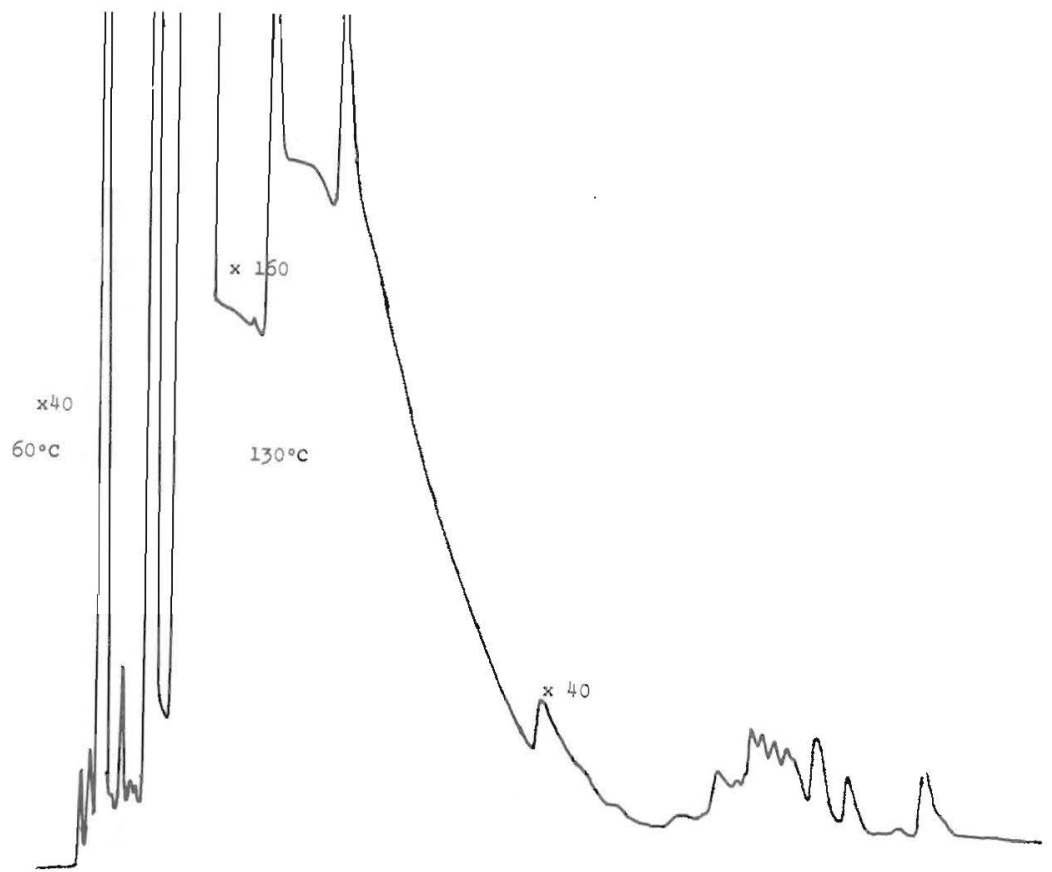

FIG. 13.-Capillary column chromatogram; rum concentrate from chromatographic separation in figure 12. Capillary column; Carbowax 20M, $150 \mathrm{ft} \times 0.01$-in i.d. Carrier flow: helium at $1 \mathrm{ml} / \mathrm{min}$ and $12 \mathrm{lb} / \mathrm{in}^{2}$. 

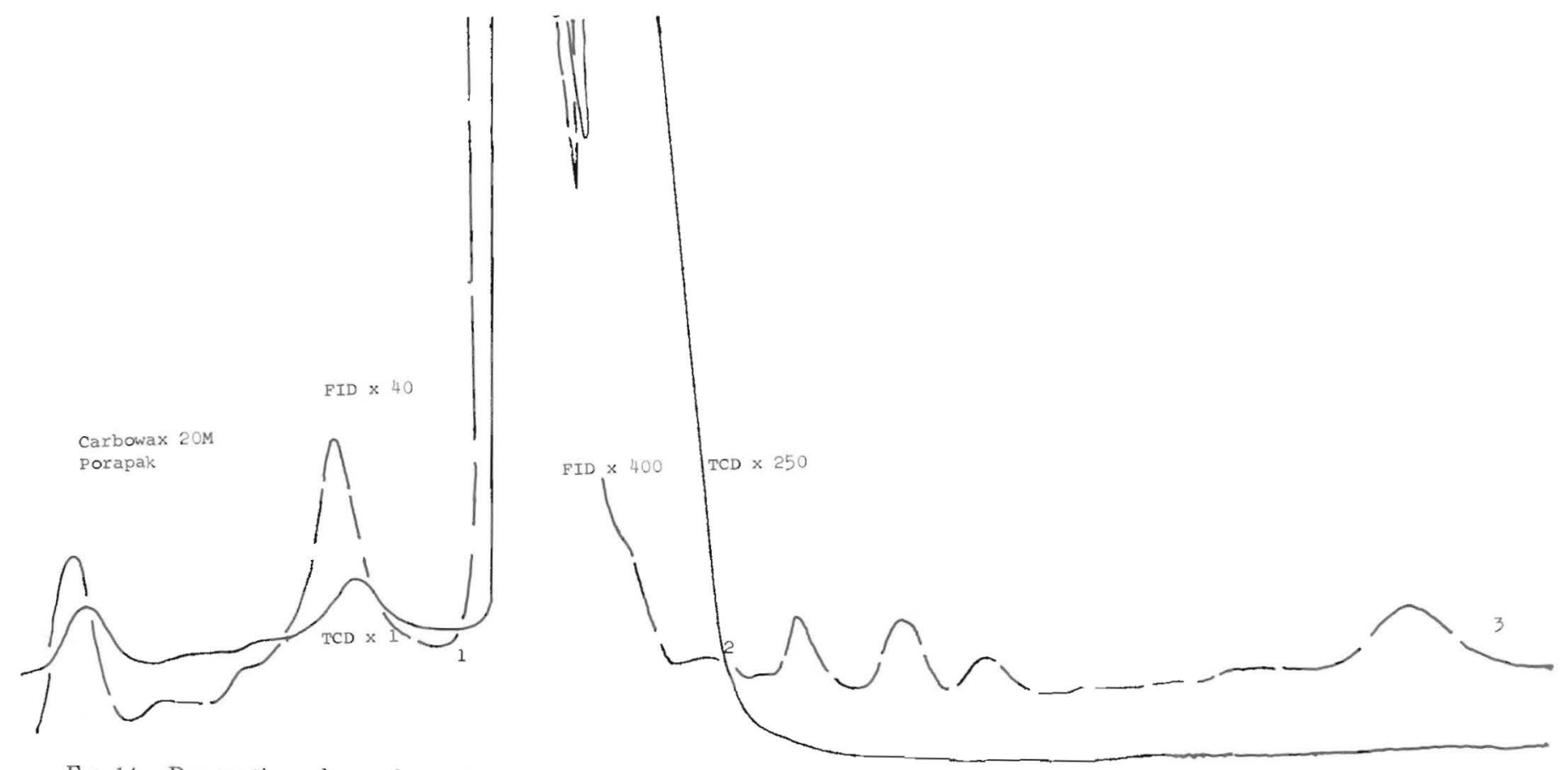

FIG. 14.-Preparative column chromatogram; $0.1 \mathrm{ml}$ commercial rum (R-612) taken in system two. Preparative columns: Porapak Q, 50/80 mesh, $7 \mathrm{ft} \times 0.5$-in o.d. followed by $20 \%$ Carbowax $20 \mathrm{M}$ coated with Chromosorb W, A/W, 60/80 mesh, $10 \mathrm{ft} \times 0.5$-in o.d. Carrier flow: helium at $150 \mathrm{ml} / \mathrm{min}$ and $40 \mathrm{lb} / \mathrm{in}^{2}$. Samples collected from positions 0 to 1 and 2 to 3 ; from 1 to 2 discarded. 
column arranged with Golay columns as in figure 2. Two capillary Golay columns were used coupled together, 50-ft SE-30 Golay column followed by 150-ft Carbowax 20M Golay column. In the experiments the Porapak Q preparative column was tested first with 1-, 2-, 3- and 5-ml rum samples using a 1/4-in o.d. trap. All the preparative chromatograms were excellent. Additional chromatograms were taken with syringe injection of $5 \mathrm{ml}$ of R-612 and another commercial light aged rum (R-621). The concentrates were trapped, transferred to $2-\mathrm{ml}$ vials, and sealed immediately. Typical preparative gas chromatograms of $5-\mathrm{ml}$ samples are shown in figures 16 and 18 with conditions in table 6 . The corresponding

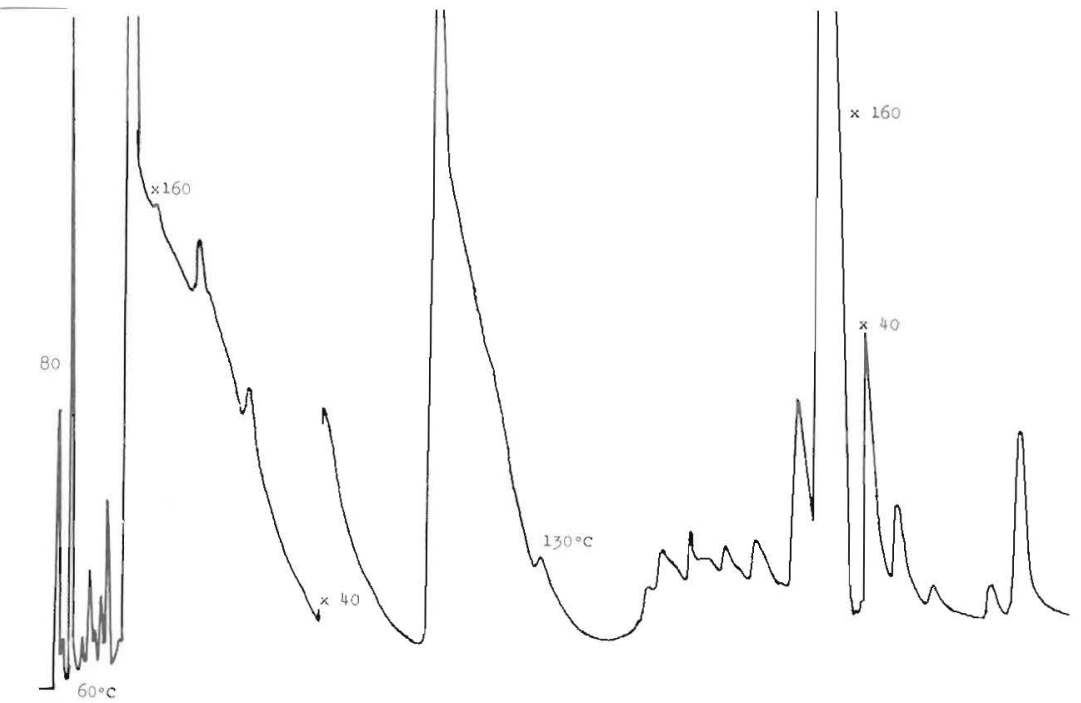

FIG. 15.-Capillary column chromatogram; rum concentrate obtained from chromatographic separation in figure 14. Capillary column: Carbowax 20M, $1.50 \mathrm{ft} \times 0.01$-in i.d. Carrier flow: helium at $1 \mathrm{ml} / \mathrm{min}$ and $12 \mathrm{lb} / \mathrm{in}^{2}$.

capillary chromatograms for $5-\mu$ injections are reproduced in figure 17 for R-612 and in figure 19 for R-621. Figure 20 is another $5-\mu$ run of R-621 in which a higher alcoholic content was used.

\section{RESULTS AND DISCUSSION}

The investigations with the first system, in which a 10 -ft $20 \%$ Carbowax 20M preparative packed column was coupled to a $150-\mathrm{ft}$ Carbowax 20M Golay, demonstrated that it is possible to combine two different gas chromatographic techniques with the same liquid phase to obtain additional signals not previously detected in Puerto Rican rums which elute prior to ethyl alcohol. The preparative capillary chromatogram (fig. 4) contains 10 different signals, 6 of which are still unidenti- 
TABLE 4.-Gas chromatographic conditions for figures 14 and 15

\begin{tabular}{|c|c|c|}
\hline & $\begin{array}{l}\text { Preparative run } \\
\text { (F \& M 810) } \\
\text { (fig. 14) }\end{array}$ & $\begin{array}{l}\text { Capillary run } \\
\text { (HP 5754B) } \\
\text { (fig. 15) }\end{array}$ \\
\hline Sample volume & $0.1 \mathrm{ml}$ & $\begin{array}{l}\text { Concentrate } \\
\text { (fig. 1) }\end{array}$ \\
\hline Injection technique & Automatic & $\begin{array}{l}\text { Concentrator } \\
\text { ( } \frac{1}{16} \text {-in o.d.) }\end{array}$ \\
\hline Injection splitter ratio & - & $1: 80$ \\
\hline Detector splitter ratio & $1: 44$ & - \\
\hline Carrier & Helium & Helium \\
\hline Carrier flow & $\begin{array}{l}150 \mathrm{ml} / \mathrm{min}(40 \\
\left.\mathrm{lb} / \mathrm{in}^{2}\right)\end{array}$ & $\begin{array}{l}1 \mathrm{ml} / \mathrm{min}(12 \\
\left.\mathrm{lb} / \mathrm{in}^{2}\right)\end{array}$ \\
\hline Oven temperature & $\begin{array}{l}65^{\circ} \text { to } 150^{\circ} \mathrm{C} \text { (HP } \\
5754 \mathrm{~B})\end{array}$ & $60^{\circ} \mathrm{C}$ \\
\hline Oven temperature program & $60^{\circ} \mathrm{C} / \mathrm{min}$ & $\begin{array}{l}20^{\circ} \mathrm{C} / \mathrm{min}\left(60^{\circ}\right. \\
\left.\text { to } 130^{\circ} \mathrm{C}\right)\end{array}$ \\
\hline Injection port temperature & $240^{\circ} \mathrm{C}$ & $240^{\circ} \mathrm{C}$ \\
\hline Injection splitter temperature & - & $140^{\circ} \mathrm{C}$ \\
\hline \multicolumn{3}{|l|}{ Detector temperature: } \\
\hline FID temperature & $250^{\circ} \mathrm{C}$ & $240^{\circ} \mathrm{C}$ \\
\hline TCD temperature & $285^{\circ} \mathrm{C}$ at $150 \mathrm{~V}$ & \\
\hline \multicolumn{3}{|l|}{ FID: } \\
\hline Hydrogen & $\begin{array}{l}35 \mathrm{ml} / \mathrm{min}(12 \\
\left.\mathrm{lb} / \mathrm{in}^{2}\right)\end{array}$ & $\begin{array}{l}35 \mathrm{ml} / \mathrm{min}(12 \\
\left.\mathrm{lb} / \mathrm{in}^{2}\right)\end{array}$ \\
\hline Air & $\begin{array}{l}450 \mathrm{ml} / \mathrm{min}(33 \\
\left.\mathrm{lb} / \mathrm{in}^{2}\right)\end{array}$ & $\begin{array}{l}450 \mathrm{ml} / \mathrm{min}(33 \\
\left.\mathrm{lb} / \mathrm{in}^{2}\right)\end{array}$ \\
\hline \multicolumn{3}{|l|}{ Column material: } \\
\hline Support & $\begin{array}{l}60 / 80, a / w, \text { Chro- } \\
\text { mosorb W }\end{array}$ & None \\
\hline Liquid phase & $20 \%$ Carbowax 20M & $\begin{array}{l}\text { Carbowax 20M } \\
\text { (Golay) }\end{array}$ \\
\hline Tubing & $\begin{array}{l}\text { Stainless steel } \\
316(10 \mathrm{ft} \times 0.5 \text {-in } \\
\text { o.d.) }\end{array}$ & $\begin{array}{l}\text { Stainless steel } \\
\quad 316(150 \mathrm{ft} \times 0.01-\text { in } \\
\text { i.d. })\end{array}$ \\
\hline Support & None & \\
\hline Liquid phase & Porapak Q, 50/80 & \\
\hline Tubing & $\begin{array}{l}\text { Stainless steel } \\
316(7 \mathrm{ft} \times 0.5 \text {-in } \\
\quad \text { o.d. })\end{array}$ & \\
\hline
\end{tabular}

fied. The chromatograms of the high efficiency technique using $1 / 8$-in o.d. columns (fig. 7 and 8) show fewer corresponding signals. The improvement in resolution attained (figs. 3, C and 4, C) is very marked although the overall duration of the chromatographic analysis (figs. 4, A; 4, B and 4, C, combined) increased substantially. The efficiency of the preparative separation is such that the amount of alcohol in the final concentrate can be reduced to a very low level, but the number of signals 
TABLE 5.-Gas chromatographic conditions for figure 9

\begin{tabular}{|c|c|}
\hline & $\begin{array}{l}\text { Preparative run } \\
\quad(\text { F \& M 810) }\end{array}$ \\
\hline Sample volume & $1 \mathrm{ml}$ \\
\hline Injection technique & Syringe \\
\hline Injection splitter ratio & - \\
\hline Detector splitter ratio & $1: 40$ \\
\hline Carrier & Helium \\
\hline Carrier flow & $102 \mathrm{ml} / \mathrm{min}\left(60 \mathrm{lb} / \mathrm{in}^{2}\right)$ \\
\hline Oven temperature & $150^{\circ} \mathrm{C}$ \\
\hline Oven temperature program & $20^{\circ} \mathrm{C} / \mathrm{min}\left(150^{\circ}\right.$ to $\left.220^{\circ} \mathrm{C}\right)$ \\
\hline Injection port temperature & $240^{\circ} \mathrm{C}$ \\
\hline Injection splitter temperature & - \\
\hline \multicolumn{2}{|l|}{ Detector temperature: } \\
\hline FID temperature & $230^{\circ} \mathrm{C}$ \\
\hline TCD temperature & $275^{\circ} \mathrm{C}$ at $150 \mathrm{~V}$ \\
\hline \multicolumn{2}{|l|}{ FID: } \\
\hline Hydrogen & $35 \mathrm{ml} / \mathrm{min}\left(12 \mathrm{lb} / \mathrm{in}^{2}\right)$ \\
\hline Air & $450 \mathrm{ml} / \mathrm{min}\left(33 \mathrm{lb} / \mathrm{in}^{2}\right)$ \\
\hline \multicolumn{2}{|l|}{ Column material: } \\
\hline Support & None \\
\hline Liquid phase & $50 / 80$, Porapak Q \\
\hline Tubing & Stainless steel 316 \\
\hline & $(10 \mathrm{ft} \times 0.5$-in o.d. $)$ \\
\hline
\end{tabular}

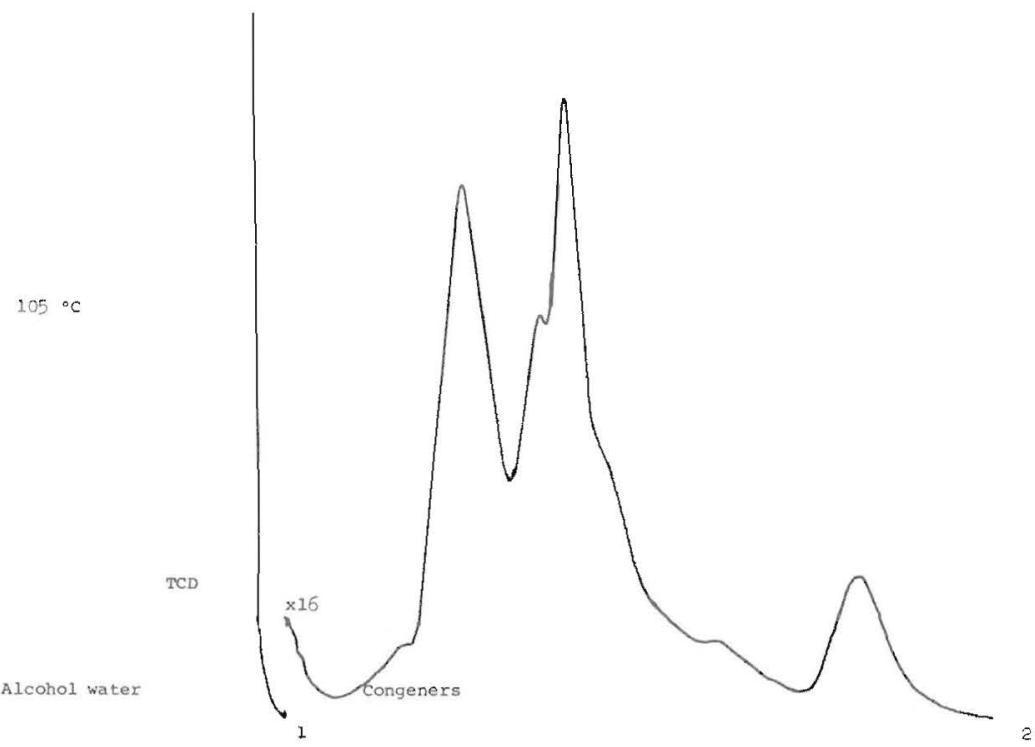

FIG. 16.-Preparative column chromatogram; $5 \mu 1$ commercial rum (R-612) taken by syringe injection. Preparative column: Porapak Q, 50/80 mesh, $7 \mathrm{ft} \times 0.5$-in o.d. Carrier flow: helium at $100 \mathrm{ml} / \mathrm{min}$ and $40 \mathrm{lb} / \mathrm{in}^{2}$. Sample collected from positions 1 to 2 , from 0 to 1 discarded. 
FID $\times 40$
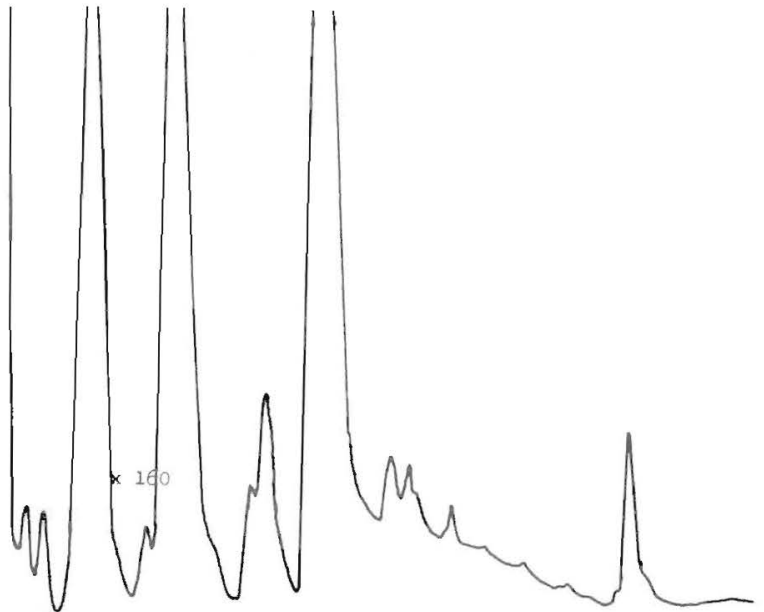

Fig. 17.-Capillary column chromatogram; $5 \mu \mathrm{l}$ commercial rum sample concentrate (R-612) taken in figure 16. Capillary columns: SE-30, $50 \mathrm{ft} \times 0.01$-in i.d. followed by Carbowax 20M, $150 \mathrm{ft} \times 0.01$-in i.d. Carrier flow: helium at $1 \mathrm{ml} / \mathrm{min}$ and $12 \mathrm{lb} / \mathrm{in}^{2}$.

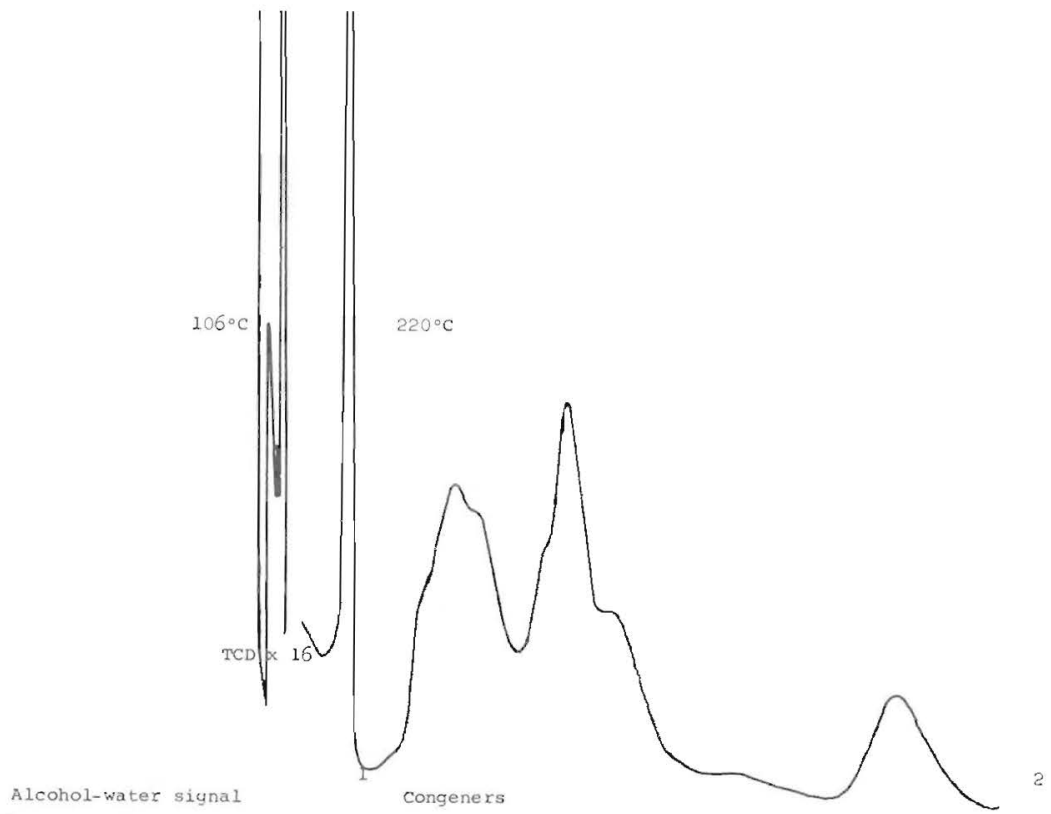

FIG. 18.-Preparative column chromatogram; $5 \mu$ commercial rum (R-621) taken by syringe injection. Preparative column: Porapak Q, 50/80 mesh, $7 \mathrm{ft} \times 0.5$-in o.d. Carrier flow: helium at $100 \mathrm{ml} / \mathrm{min}$ and $40 \mathrm{lb} / \mathrm{in}^{2}$. Sample collected from positions 1 to 2 , from 0 to 1 discarded. 
in the capillary chromatogram depends to a large extent on the preparative carrier flow rate. The ethyl alcohol content of the concentrate corresponding with the last signal of figure 3, C, was very low and corresponds with an early cut, position 1, in the preparative last signal. The capillary chromatograms (fig. 4, C) show a more intense signal for ethyl alcohol due to a later cut (position 1) during the preparative separation. The collection procedure at this point is highly efficient, insuring reproducibility of the analysis. In the experiment Carbowax

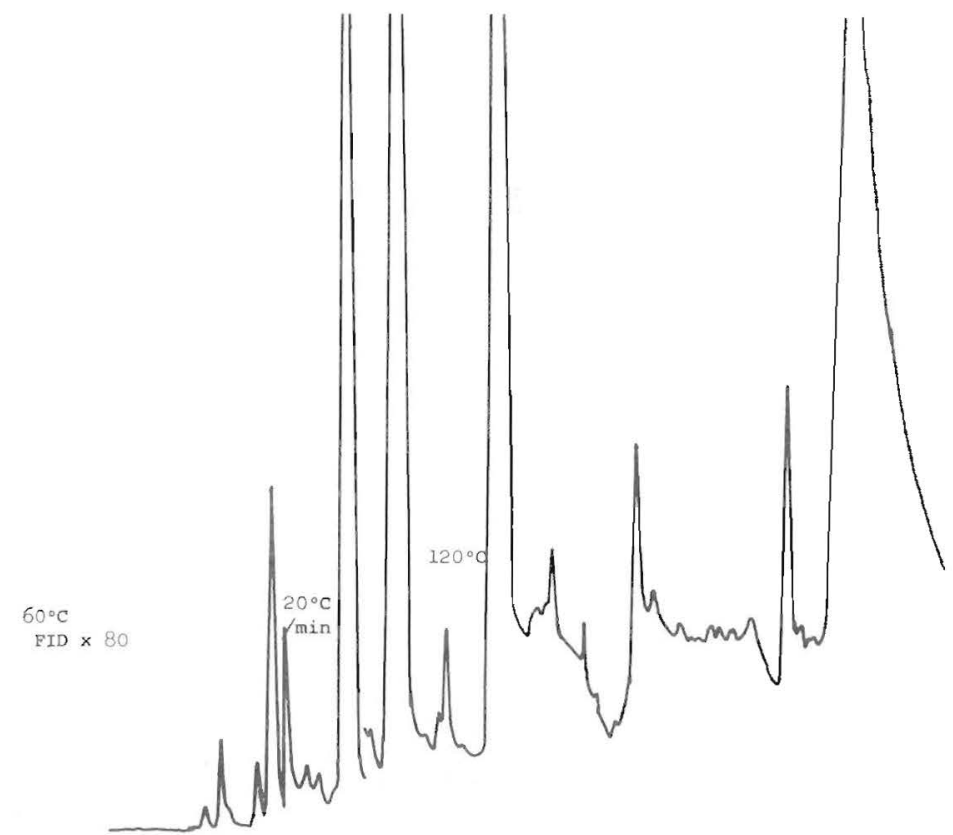

Fig. 19.-Capillary column chromatogram; $5 \mu \mathrm{l}$ commercial rum sample concentrate (R-621) taken in figure 18. Capillary columns: SE-30, $50 \mathrm{ft} \times 0.01$-in i.d. followed by Carbowax 20M, $150 \mathrm{ft} \times 0.01$-in i.d. Carrier flow: helium at $1 \mathrm{ml} / \mathrm{min}$ and $12 \mathrm{lb} / \mathrm{in}^{2}$.

$20 \mathrm{M}$ proved to be the best liquid phase to investigate the composition of alcoholic beverages in terms of congeners that elute prior to ethyl alcohol but is not suitable to obtain those fractions containing the heavy congeners because these are separated in a mixture with the alcohol and the water.

The results obtained with a similar system provided with a 7 - or a 10-ft Porapak Q packed preparative column were not as good as those obtained with a $20 \%$ Carbowax 20M. The preparative chromatograms reproduced (figs. 9 and 10) are excellent and illustrate the feasibility of removing most water and ethyl alcohol from an alcoholic beverage, 

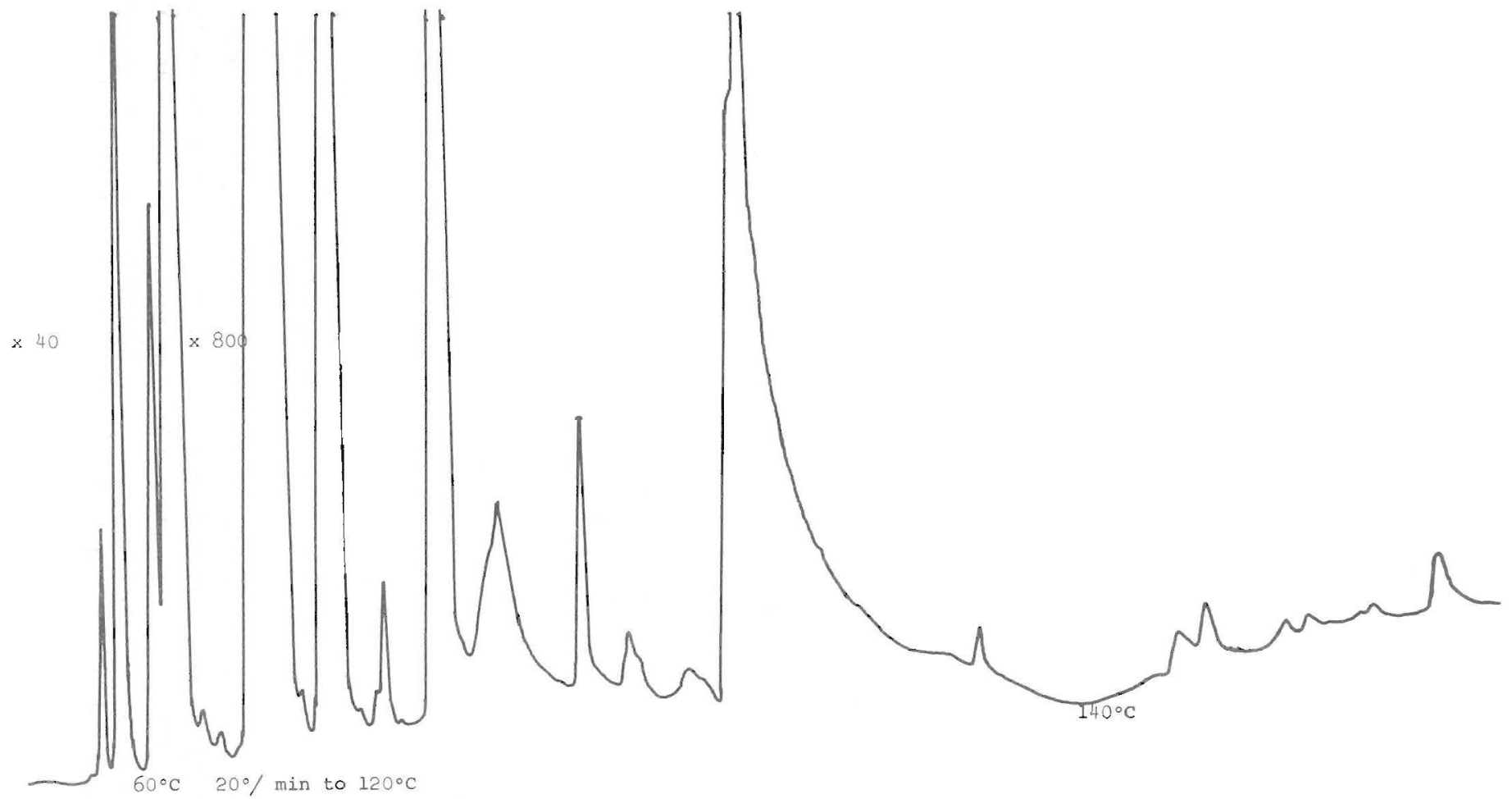

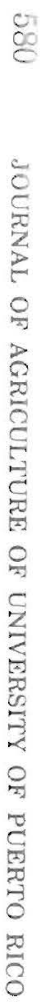

FIG. 20.-Capillary column chromatogram; $5 \mu \mathrm{l}$ commercial rum sample concentrate (R-621) taken from $5 \mathrm{ml}$ of rum. Capillary column: SE-30, $50 \mathrm{ft} \times 0.01$-in i.d. followed by Carbowax $20 \mathrm{M}, 150 \mathrm{ft} \times 0.01$-in i.d. Carrier flow: helium at $1 \mathrm{ml} / \mathrm{min}$ and $12 \mathrm{lb} / \mathrm{in}^{2}$. 
TABLE 6.-Gas chromatographic conditions for figures 10, 16 through 20

\begin{tabular}{|c|c|c|}
\hline & $\begin{array}{c}\text { Preparative run } \\
\text { (F \& M 810) } \\
\text { (fig. } 10,16 \text { and } 18 \text { ) }\end{array}$ & $\begin{array}{c}\text { Capillary run } \\
(\text { HP } 5754 \mathrm{~B}) \\
\text { (fig. 17, 19 and 20) }\end{array}$ \\
\hline Sample volume & $5 \mathrm{ml}$ & $5 \mu \mathrm{l}$ (fig. 2) \\
\hline Injection technique & Syringe & $\begin{array}{r}\text { Concentrator } \\
(1 / 4-\text { in o.d. })\end{array}$ \\
\hline Injection splitter ratio & - & $1: 40$ \\
\hline Carrier & Helium & Helium \\
\hline Carrier flow & $\begin{array}{l}100 \mathrm{ml} / \mathrm{min}(40 \\
\left.1 \mathrm{~b} / \mathrm{in}^{2}\right)\end{array}$ & $\begin{array}{l}1 \mathrm{ml} / \mathrm{min}(12 \\
\left.\mathrm{lb} / \mathrm{in}^{2}\right)\end{array}$ \\
\hline Oven temperature program & $\begin{array}{l}60^{\circ} \mathrm{C} \cdot \min \left(105^{\circ}\right. \\
\left.\text { to } 220^{\circ} \mathrm{C}\right)\end{array}$ & $\begin{array}{l}20^{\circ} \mathrm{C} / \min \left(60^{\circ}\right. \\
\left.\text { to } 120^{\circ} \mathrm{C}\right)\end{array}$ \\
\hline Injection port temperature & $240^{\circ} \mathrm{C}$ & $240^{\circ} \mathrm{C}$ \\
\hline Injection splitter temperature & - & $140^{\circ} \mathrm{C}$ \\
\hline \multicolumn{3}{|l|}{ Detector temperature: } \\
\hline FID temperature & $240^{\circ} \mathrm{C}$ & $240^{\circ} \mathrm{C}$ \\
\hline TCD temperature & $285^{\circ} \mathrm{C}$ at $150 \mathrm{~V}$ & \\
\hline \multicolumn{3}{|l|}{ FID: } \\
\hline Hydrogen & $\begin{array}{c}35 \mathrm{ml} / \mathrm{min}(12 \\
\left.\mathrm{lb} / \mathrm{in}^{2}\right)\end{array}$ & $\begin{array}{l}35 \mathrm{ml} / \mathrm{min}(12 \\
\left.\mathrm{lb} / \mathrm{in}^{2}\right)\end{array}$ \\
\hline Air & $\begin{array}{l}450 \mathrm{ml} / \mathrm{min}(33 \\
\left.\mathrm{lb} / \mathrm{in}^{2}\right)\end{array}$ & $\begin{array}{l}450 \mathrm{ml} / \mathrm{min}(33 \\
\left.\mathrm{lb} / \mathrm{in}^{2}\right)\end{array}$ \\
\hline \multicolumn{3}{|l|}{ Column material: } \\
\hline Support & None & None \\
\hline Liquid phase & 50/80, Porapak Q & $\begin{array}{l}\text { Carbowax 20M } \\
\text { (Golay) }\end{array}$ \\
\hline Tubing & $\begin{array}{l}\text { Stainless steel } \\
316(7 \mathrm{ft} \times 0.5 \text {-in } \\
\text { o.d.) }\end{array}$ & $\begin{array}{l}\text { Stainless steel } \\
316(150 \mathrm{ft} \times 0.01 \text {-in } \\
\text { i.d.) }\end{array}$ \\
\hline Support & & None \\
\hline Liquid phase & & $\begin{array}{l}\text { SE-30 (silicone } \\
\text { gum) }\end{array}$ \\
\hline Tubing & & $\begin{array}{l}\text { Stainless steel } \\
316(150 \mathrm{ft} \times 0.1 \text {-in } \\
\text { i.d.) }\end{array}$ \\
\hline
\end{tabular}

leaving a concentrate rich in congeners. Attempts to analyze this concentrate by direct injection into a capillary Golay column failed because of the strong broadening of the chromatographic signals. The system with the Porapak Q preparative column was found to be deficient as such to get a complete direct analysis of rum, although the data obtained were useful in the development of the two further systems.

The second system, in which the 7 -ft Porapak Q packed preparative column followed by the 10 -ft Carbowax $20 \mathrm{M}$ was coupled to the 150 - $\mathrm{ft}$ Carbowax 20M Golay column, demonstrated that it is possible to reach a complete direct separation of the concentrate collected from a $0.1-\mu \mathrm{l}$ rum sample when using a 1/16-in o.d. trap. Other traps investigated for collection of the concentrates arising from larger rum samples were found 
to be unsuitable for direct injection because the Golay column signals were unresolved due to the broadening caused by congeners that elute after ethyl alcohol on Carbowax 20M. In general the system works efficiently for the separation of those congeners which elute prior to ethyl alcohol, but only seven congeners were detected in this region of the chromatograms (figs. 11 and 13). Inspection of the chromatogram in figure 13 shows the presence of about 30 congeners in a commercial Puerto Rican rum. The part of the system with the two preparative columns is useful for separating water and ethyl alcohol as a single signal (fig. 12).

The third system with the 7-ft Porapak Q preparative column, developed in the present study, does not provide a direct method for analysis of rum. However, an excellent separation of rum was achieved with only a few of the volatile congeners missing. The Golay column chromatograms, reproduced in figures 17,19 , and 20, and obtained in the last step of the system, show that about 40 congeners can be detected in two commercial Puerto Rican rums. An advantage of this system is that it is useful for repetitive capillary injection. Therefore, it is appropriate for identification purposes.

Successful preparative-capillary techniques were performed with the systems developed and described herein. While this technology still needs a great deal of refinement, the results obtained are better than those reported previously. This is the first instance in which preparative and capillary column separations have been unified into a simple and versatile technique for the analysis of alcoholic beverages.

\section{RESUMEN}

Se describe el desarrollo de tres sistemas cromatográficos de vapor útiles para el análisis de congenéricos presentes en trazas en los rones y se discuten algunos de los resultados cualitativos obtenidos. Los sistemas emplean columnas preparatorias para obtener concentrados de algunos de los congenéricos de los rones, los cuales luego se analizan en columnas capilares del tipo Golay. En los primeros dos sistemas, se acopló directamente la columna preparatoria a la columna capilar. El concentrado obtenido en la columna preparatoria se condensó en un colector de acero inoxidable de poco volumen y se analizó simultáneamente en la columna capilar luego de haber calentado rápidamente el colector. El tercer sistema empleó el mismo equipo, pero un colector de mayor volumen transfirió la muestra concentrada a una ampolleta de $2 \mathrm{ml}$. antes de ser analizada en columnas capilares. El primer sistema con columna preparatoria de 10 pies de largo y 0.5 pulgada de diámetro exterior cargada con $20 \%$ de Carbowax $20 \mathrm{M}$ y Chromosorb W, lavado con ácido, un cedazo de 60/80 mallas, seguida por una columna capilar de 150 pies $\times 0.01$ pulgada de diámetro interior impregnada con Carbowax 20M, dió magnificos resultados en el análisis del aroma del ron, logrando separar 10 congéneres antes de obtener la señal de alcohol etílico. Un sistema similar, con una columna preparatoria de 10 pies $\times 0.5$ pulgada de diámetro exterior y la columna capilar de Porapak $Q$, con un cedazo de $50 / 80$, mallas no fue tan eficaz por el ensanchamiento de las señales. El segundo sistema, que utiliza la columna preparatoria de 10 pies de $20 \%$ Carbowax 20M, seguida por la de 10 pies de Porapak Q, acopladas 
a la columna capilar de Carbowax $20 \mathrm{M}$ y que utiliza colectores de $1 / 8$ y $1 / 16$ pulgada de diámetro exterior fue capaz de separar unos 30 congenéricos y además hizo posible obtener agua y alcohol como una sola señal. Una columna de 7 pies $\times 0.5$ pulgada de diámetro exterior cargada con Porapak Q, cedazo 50/80, se probó en el tercer sistema, provisto con un colector de $1 / 4$ pulgada de diámetro exterior. Con este sistema se lograron señales de unos 40 congenéricos en el concentrado utilizando una columna capilar de 50 pies $\times 0.1$ pulgada de diametro interior, impregnada de SE-30 y seguida por la de 150 pies de Carbowax 20M. Los resultados de esta investagación demostraron que, utilizando sistemas similares a los estudiados, es factible hacer un análisis de bebidas alcohólicas destiladas mucho más completo que lo que se ha hecho hasta la fecha por otros métodos.

\section{LITERATURE CITED}

1. Baraud, J., and Maurice, A., Les alcohols et esters des eaux-de-vie de canne et de pomme, Ind. Aliment. Agr. 80: 1, 1963.

2. Bayer, E., Quality and flavor by gas chromatography, J. Gas Chromatog. 4: 67-73, 1966.

3. Bober, A., and Haddaway, L. W., Gas chromatographic identification of alcoholic beverages, J. Gas Chromatogr. 1: 8-13, 1963.

4. - and - Gas chromatographic identification of alcoholic beverages, J. Gas Chromatogr. 2: 76-9, 1964.

5. Duncan, R. E. B., and Philip, J. M., Methods for the analysis of scotch whiskey, J. Sci. Food. Agric. 17: 208-14, 1966.

6. Fouassin, A., L'analyse des spiritueux par chromatographique en phase vapeur, Rev. Ferment. Ind. Aliment. 14: 206-12, 1959.

7. García, M., Aguilera, C., and Sánchez de Torres, C., Analysis of Puerto Rican rums by gas chromatography, Proc. XII Congr., I.S.S.C.T., Elsevier Publishing Co., Amsterdam, Holland, Feb. 1965.

8. Kahn, J. H., Compounds identified in whiskey, wine, and beer, A Tabulation, J. of the Assoc. Offic. Ancil. Chem. 52: 1166-75, 1969.

9. Kepner, R. E., Maarse, H., and Strating, J., Gas chromatographic head space techniques for the quantitative determination of volatile components in multicompounds aqueous solutions, J. Anal. Chem. 36: 77-82, 1964.

10. Liebich, H. M., Koening, W. A., and Bayer, E., The analysis of the flavor of rum by gas-liquid chromatography and mass spectrometry. J. Chromatogr. Sci. 8: 527-33, 1970.

11. Maarse, $H_{\text {,, }}$ and ten Noever de Brau, M. C., The analysis of volatile components of Jamaica rum, Food Sci. 31: 951-5, 1966.

12. Maurel, A. J., Étude chromatographique en phase gazeuse des constituents des rhums, Compt. Rend. Acad. Agr. France 50: 52, 1964.

13. - and Lafarge, J. P., Etude dex eaux-de-vie par chromatographie en phase gazeuse, Compt. Rend. Acad. Agr. France 49: 332, 1963.

14. Methodology, Higher Alcohols (n-propyl alcohol, isobutyl alcohol, isoamyl alcohol) and ethyl acetate, Methods of Analysis, Assoc. Offic. Anal. Chem., 11th ed. p. 151, 1970.

15. Nykanen, L., Puputti, E., and Suomalainen, H., Volatile fatty acids in some brands of whiskey, cognac and rum, J. Food Sci. 33: 88-92, 1968.

16. Sanchez de Torres, C., and Aguiar, J. L., Colorimetric analysis of fusel oil in rums using o-nitrobenzaldehyde as color reagent, J. Agr. Univ. P.R. 54(1): 96-109, 1970.

17. Sihto, E., Nykanen, L., and Suomalainen, H., Gas chromatography of the aroma compounds of alcoholic beverages, Teknilisen Kemian Aikkauslehti 19: 753-62, 1962.

18. Singer, D. D., and Stile, J. W., The determination of higher alcohol in potable spirits, Analyst 90: 290-6, 1965. 
19. Stevens, R. K., and Martin, G. E., Gas chromatographic identification of ethyl esters of fatty acids in domestic and imported rums, J. Assoc. Offic. Agr. Chem. 48: 802-5, 1965.

20. Suomalainen, H., Fluchtige begleitstoffe in gärungslosungen isbesondere in alkoholischen getränken, Branntweinwirtschaft 105: 1, 1965.

21. — and Nykanen, L., Methods applied in study of aroma of alcoholic beverages, Wallerstein Lab. Comm. 31: 5-13, 1968.

22. Technical Staff, Rum Pilot Plant, Manual de métodos analíticos de la planta piloto de ron, (MPPR-1), Agr. Exp. Sta. Univ. P.R., Río Piedras, P.R., January, 1969.

23. Timmer, R., ter Heide, R., Wobben, H. J., and de Valois, P. J., Phenolic compounds in rum, J. Food Sci. 36: 462-3, 1971.

24. Williams, A. A., and Tucnott, O. F., The volatile components of scotch whiskey, J. Sci. Food Agr. 23: 1-7, 1972. 